\title{
Draft Principles, Policy, and Acceptance Criteria for Decommissioning of U.S. Department of Energy Contaminated Surplus Facilities and Summary of International Decommissioning Programs
}

by B.K. Singh, ${ }^{*}$ J. Gillette, and J. Jackson

Center for Cost Engineering,

Decision and Information Sciences Division,

Argonne National Laboratory, 9700 South Cass Avenue, Argonne, Illinois 60439

December 1994

Work sponsored by United States Department of Energy,

Assistant Secretary for Environment, Safety, and Health

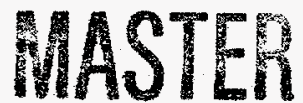

* Singh is Deputy Director of the Systems Analysis and Standards Division, Office of Nuclear Safety Poljcy and Standards, U.S. Department of Energy. 


\section{DISCLAMMER}

Portions of this document may be illegible in electronic image products. Images are produced from the best available original document. 


\section{CONTENTS}

ACKNOWLEDGMENTS $\ldots \ldots \ldots \ldots \ldots \ldots \ldots \ldots \ldots \ldots \ldots \ldots \ldots \ldots \ldots \ldots$ vi

NOTATION $\ldots \ldots \ldots \ldots \ldots \ldots \ldots \ldots \ldots \ldots \ldots \ldots \ldots \ldots \ldots \ldots \ldots \ldots \ldots$ vii

$1 \quad$ INTRODUCTION $\ldots \ldots \ldots \ldots \ldots \ldots \ldots \ldots \ldots \ldots \ldots \ldots \ldots \ldots \ldots \ldots \ldots$

$2 \quad$ BACKGROUND $\ldots \ldots \ldots \ldots \ldots \ldots \ldots \ldots \ldots \ldots \ldots \ldots \ldots \ldots \ldots$

3 DECOMMISSIONING HISTORY, POLICY, AND PRINCIPLES $\ldots \ldots \ldots \ldots \ldots$

4 DOE ORDER ON DECOMMISSIONING OF CONTAMINATED SURPLUS FACILITIES $\ldots \ldots \ldots \ldots \ldots \ldots \ldots \ldots \ldots \ldots \ldots \ldots \ldots \ldots$

5 ACCEPTANCE CRITERIA FOR DECOMMISSIONING PLANS $\ldots \ldots \ldots \ldots \ldots$

5.1 Facility Description and History $\ldots \ldots \ldots \ldots \ldots \ldots \ldots \ldots \ldots \ldots$

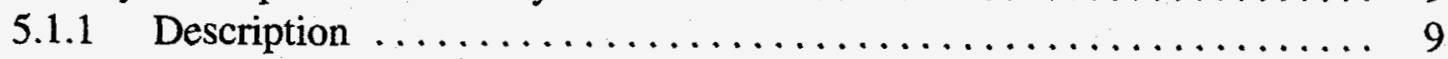

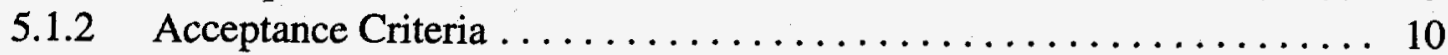

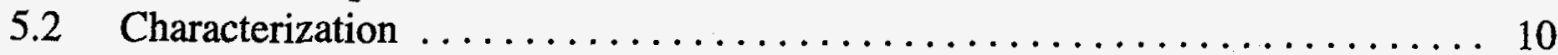

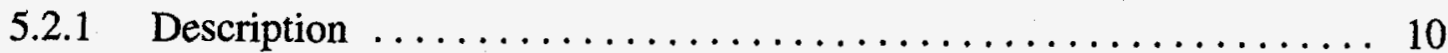

$5.2 .2 \quad$ Acceptance Criteria . . . . . . . . . . . . . . . . . . . . 11

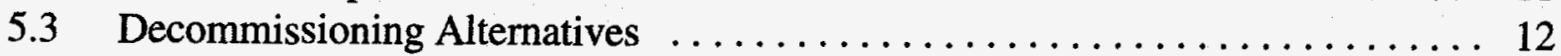

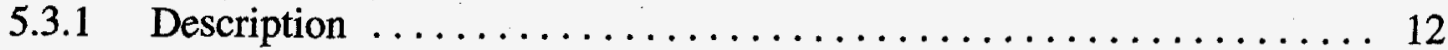

5.3.2 Acceptance Criteria . . . . . . . . . . . . . . . . . . . . 13

5.4 Environmental Review Process and Cleanup Criteria $\ldots \ldots \ldots \ldots \ldots \ldots \ldots \ldots$

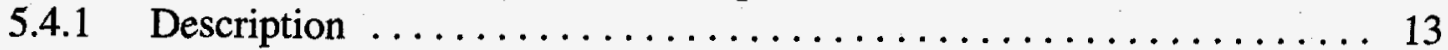

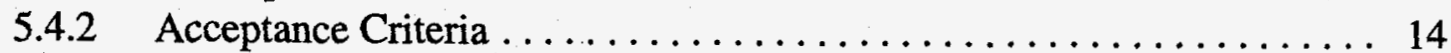

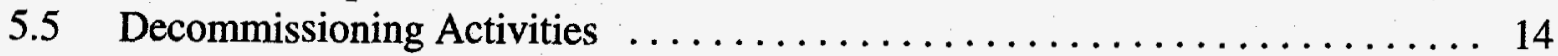

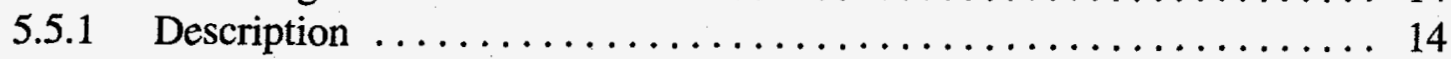

$5.5 .2 \quad$ Acceptance Criteria . . . . . . . . . . . . . . . . . . 15

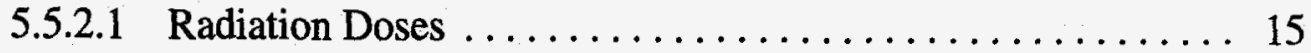

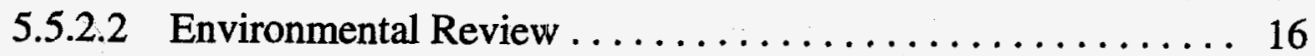

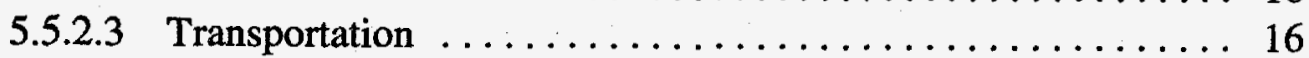

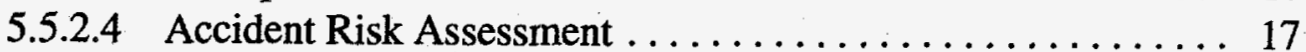

5.5.2.5 Worker and Public Safety $\ldots \ldots \ldots \ldots \ldots \ldots \ldots \ldots$

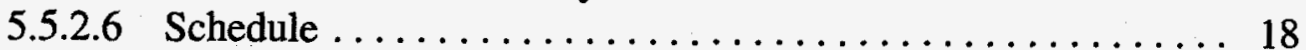

5.6 Organization and Program Management $\ldots \ldots \ldots \ldots \ldots \ldots \ldots \ldots \ldots \ldots$

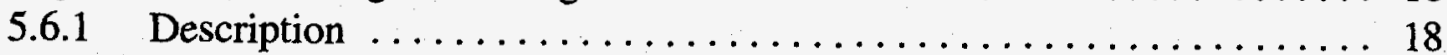

5.6 .2 Acceptance Criteria .......................... 19

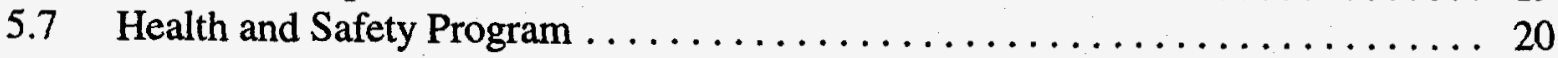

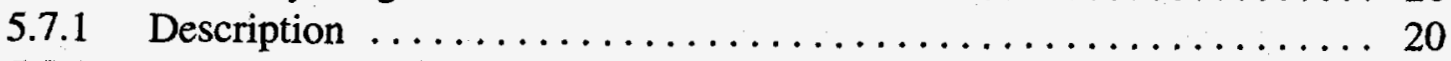

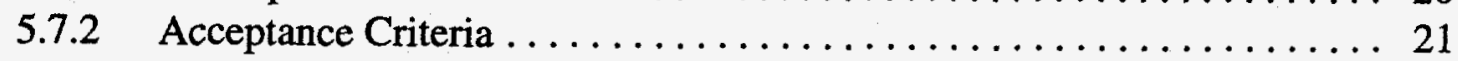




\section{CONTENTS (Cont.)}

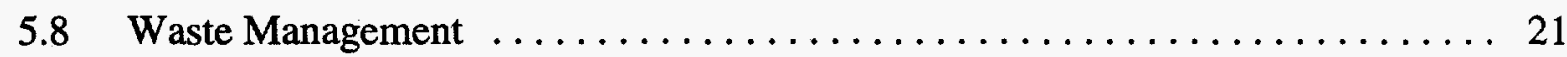

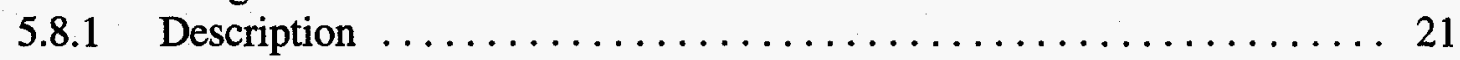

5.8.2 Acceptance Criteria ............................. 22

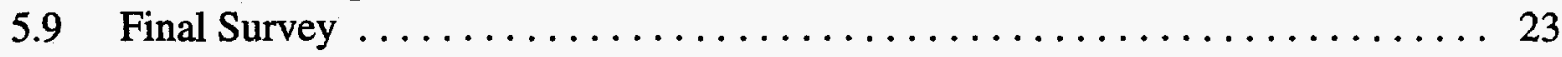

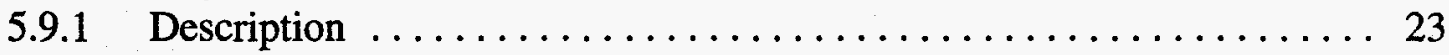

5.9.2 Acceptance Criteria . . . . . . . . . . . . . . . . . . . . . . . 23

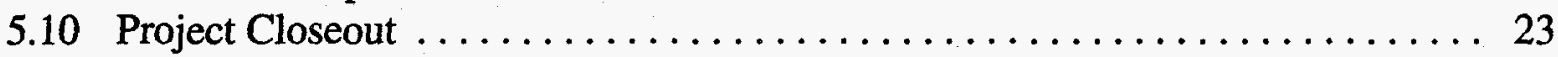

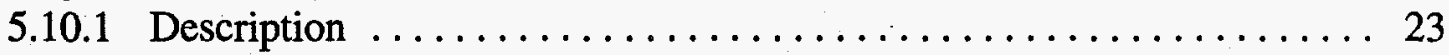

5.10 .2 Acceptance Criteria . . . . . . . . . . . . . . . . . . . 24

\section{SUMMARY OF SELECTED INTERNATIONAL DECOMMISSIONING}

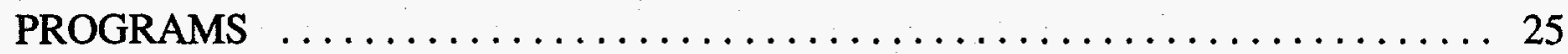

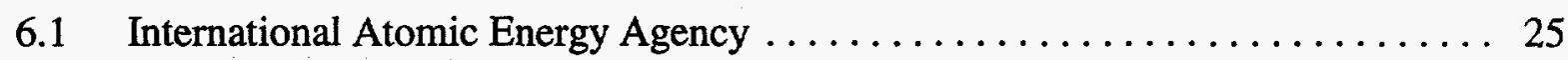

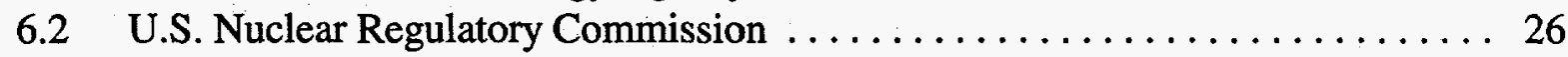

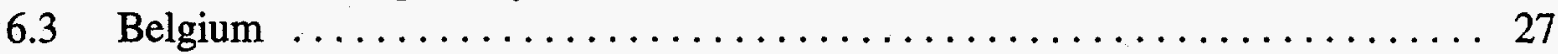

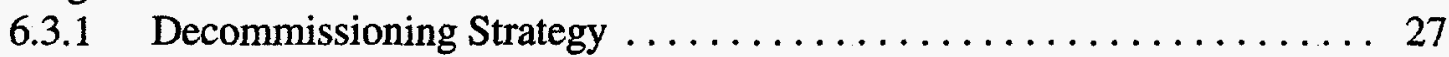

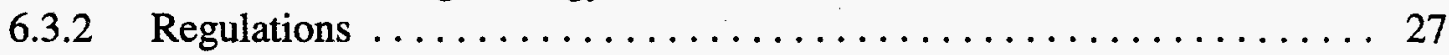

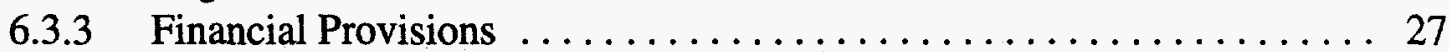

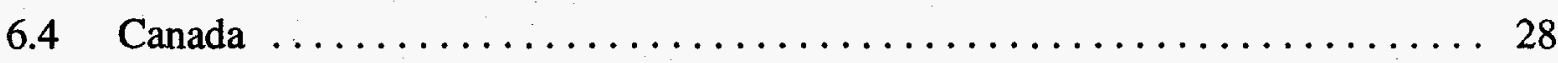

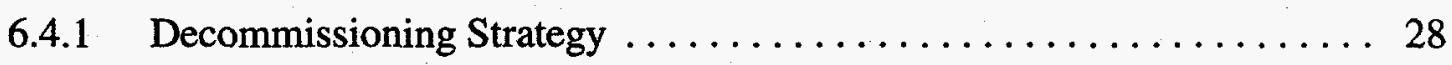

6.4 .2 Regulations ................................. 29

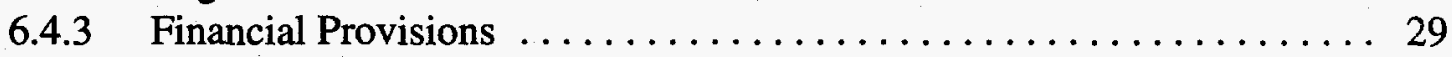

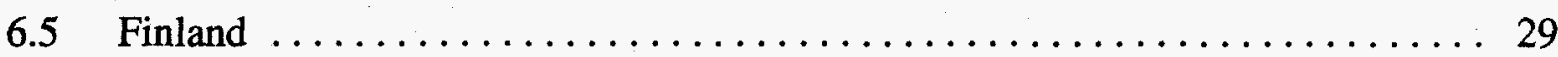

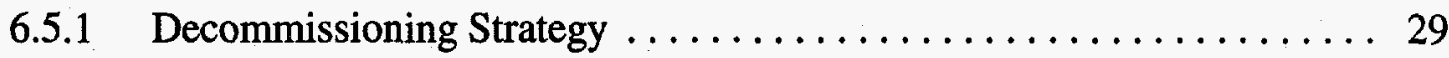

6.5.2 Regulations . ................................ 30

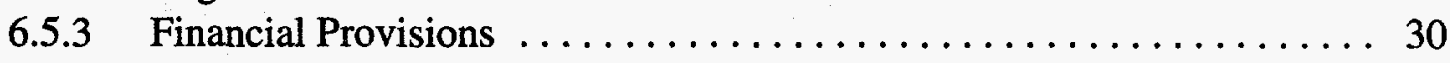

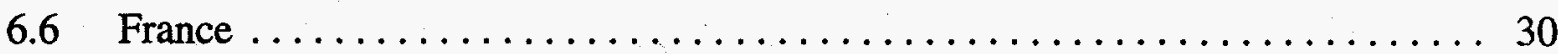

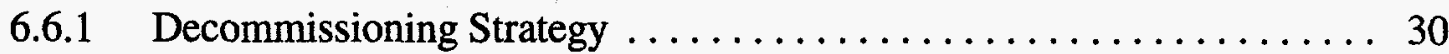

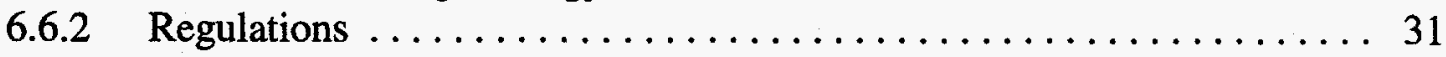

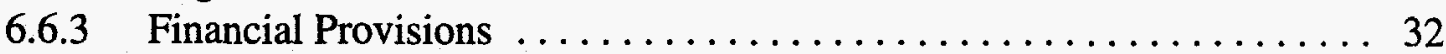

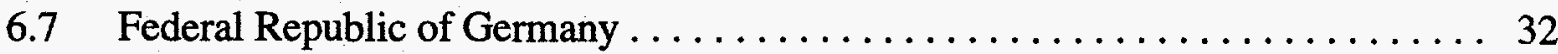

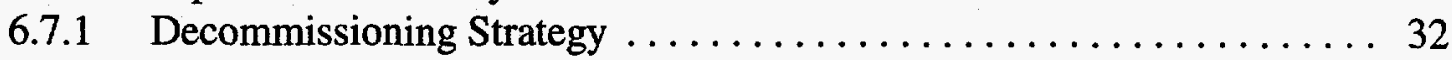

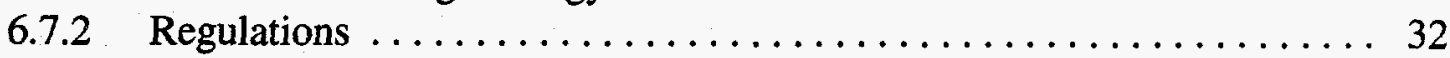

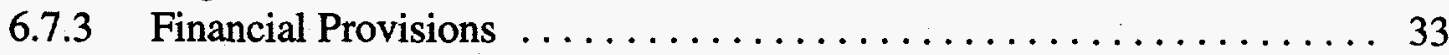

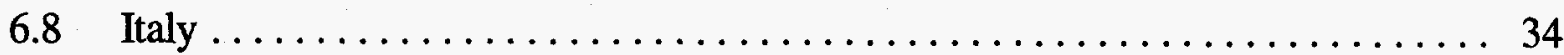

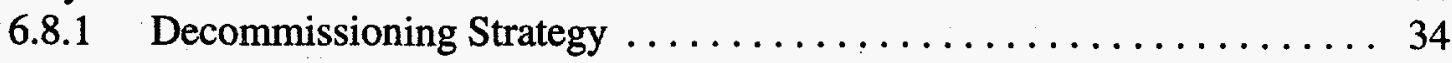

6.8.2 Regulations ................................... 34

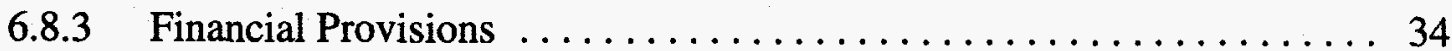

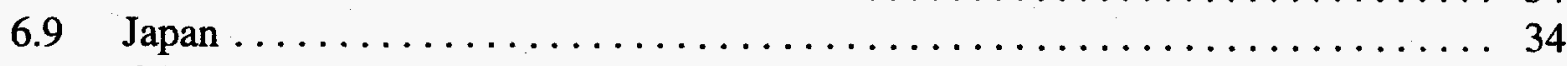

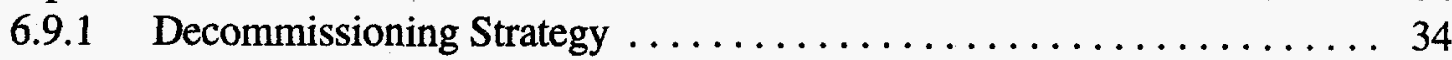

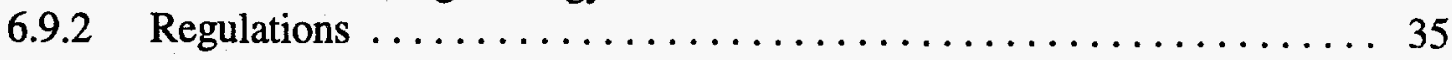

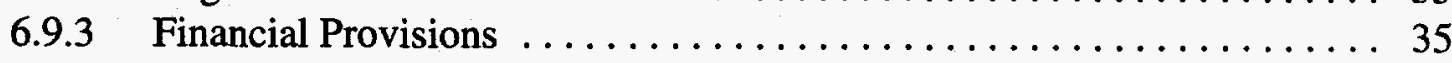




\section{CONTENTS (Cont.)}

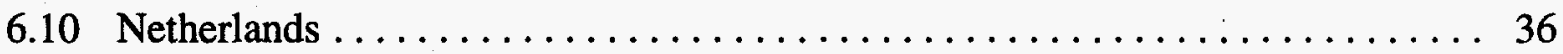

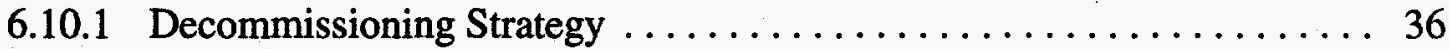

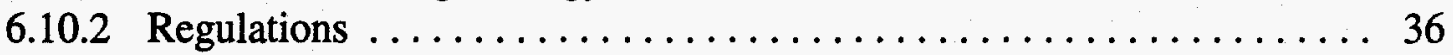

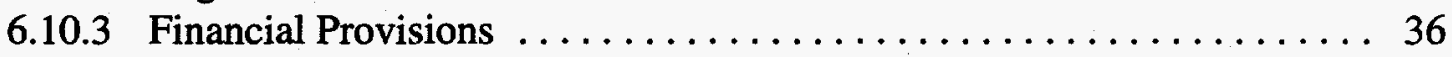

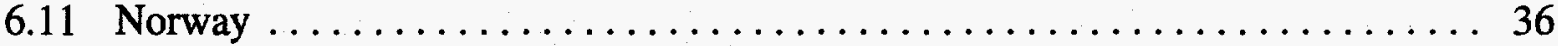

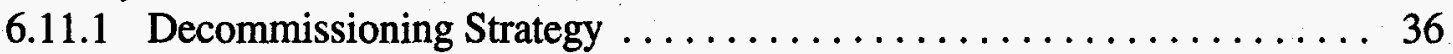

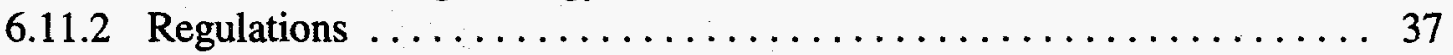

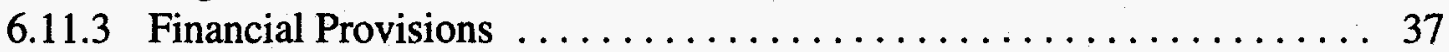

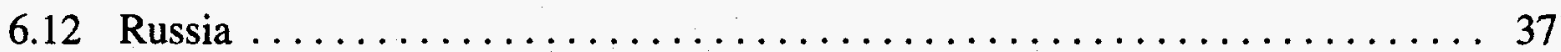

6.12.1 Decommissioning Strategy $\ldots \ldots \ldots \ldots \ldots \ldots \ldots \ldots \ldots \ldots \ldots \ldots \ldots \ldots \ldots$

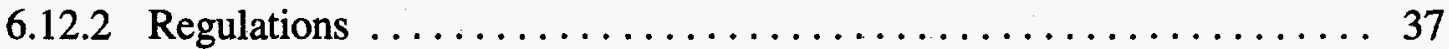

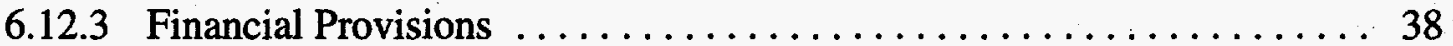

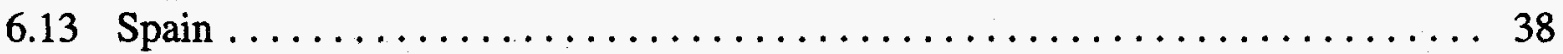

6.13.1 Decommissioning Strategy $\ldots \ldots \ldots \ldots \ldots \ldots \ldots \ldots \ldots \ldots \ldots \ldots, \ldots \ldots \ldots$

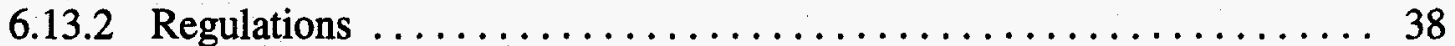

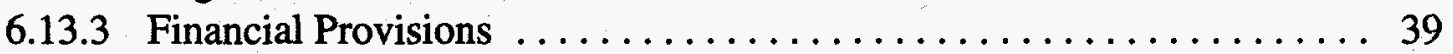

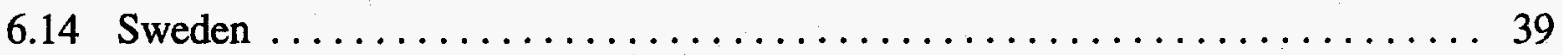

6.14.1 Decommissioning Strategy $\ldots \ldots \ldots \ldots \ldots \ldots \ldots \ldots \ldots \ldots \ldots \ldots \ldots$

6.14 .2 Regulations ................................... 39

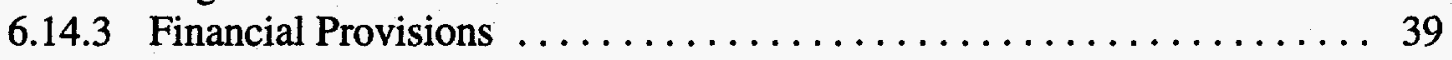

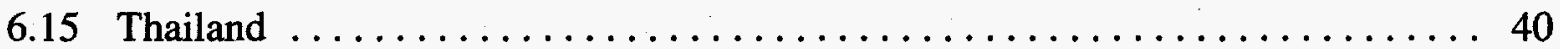

6.15.1 Decommissioning Strategy $\ldots \ldots \ldots \ldots \ldots \ldots \ldots \ldots \ldots \ldots, 40$

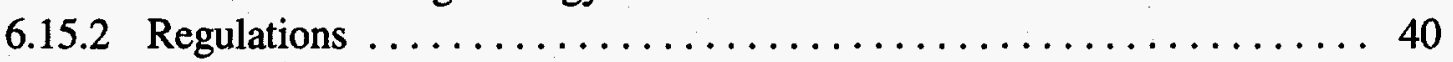

6.15.3 Financial Provisions ............................. 41

6.16 United Kingdom $\ldots \ldots \ldots \ldots \ldots \ldots \ldots \ldots \ldots \ldots \ldots \ldots \ldots \ldots, 41$

6.16.1 Decommissioning Strategy $\ldots \ldots \ldots \ldots \ldots \ldots \ldots \ldots \ldots \ldots, 41$

6.16 .2 Regulations $\ldots \ldots \ldots \ldots \ldots \ldots \ldots \ldots \ldots \ldots \ldots \ldots \ldots, 42$

6.16.3 Financial Provisions $\ldots \ldots \ldots \ldots \ldots \ldots \ldots \ldots \ldots \ldots \ldots \ldots, \ldots \ldots \ldots$

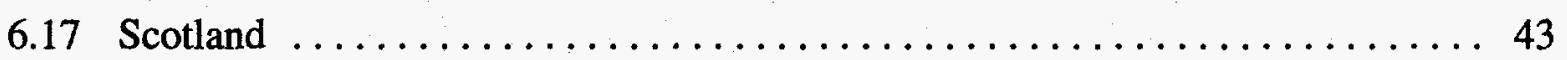

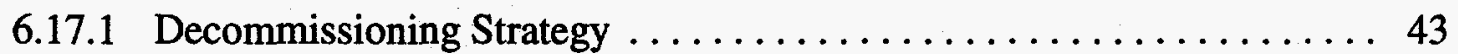

6.17 .2 Regulations $\ldots \ldots \ldots \ldots \ldots \ldots \ldots \ldots \ldots \ldots \ldots \ldots \ldots \ldots, 44$

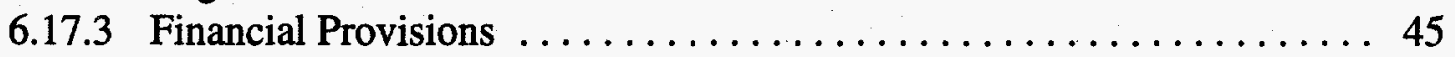

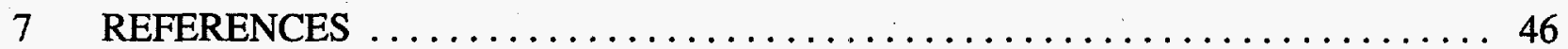

Appendix A: Draft Department of Energy Order 5820.DDD, Decommissioning of U.S. Department of Energy Contaminated Surplus Facilities $\ldots \ldots \ldots .51$

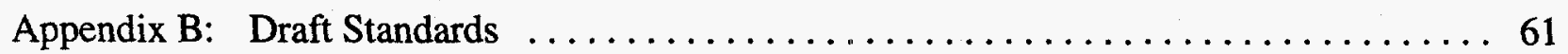




\section{ACKNOWLEDGMENTS}

The authors acknowledge and appreciate the efforts of several people in helping us prepare this document. We acknowledge Richard M. Stark, Director of the Systems Analysis and Standards Division, U.S. Department of Energy (DOE) Office of Nuclear Safety Policy and Standards, for his guidance and helpful suggestions on this project, particularly on the acceptance criteria. We also acknowledge the work by Patricia R. Worthington, DOE Office of Nuclear Safety Risk and Policy, in developing many of the decommissioning principles presented in this document. Several colleagues at Argonne National Laboratory, including Larry Boing, Mike Coffey, and Al Knox, provided us with valuable material and insight. We acknowledge the contributions of Ankur Purohit, in helping to coordinate the overall activities. Cathy Hooper was instrumental in obtaining information on relevant DOE orders and acceptance criteria for decommissioning programs and in organizing much of the material. Many other people involved in decommissioning of contaminated facilities throughout the DOE complex also made valuable contributions to this document. We particularly acknowledge Peter Soo, Brookhaven National Laboratory, for his valuable and insightful review of the draft DOE order, "Decommissioning of U.S. Department of Energy Contaminated Surplus Facilities." 


\section{NOTATION}

AECL Atomic Energy of Canada Limited (Canada)

ALARA as low as reasonably achievable

BMU Federal Ministry for the Environmental Protection

of Nature and Reactor Safety (Germany)

$\mathrm{Bq} / \mathrm{g} \quad$ becquerel(s) per gram

$\mathrm{Bq} / \mathrm{m}^{2} \quad$ becquerel(s) per square meter

CERCLA Comprehensive Environmental Response, Compensation, and Liability Act

D\&D decontamination and decommissioning

DOE U.S. Department of Energy

ES\&H environment, safety, and health

HSE Health and Safety Executive (Scotland)

IAEA International Atomic Energy Agency

mrem/yr millirem(s) per year

NEPA National Environmental Policy Act

NRC U.S. Nuclear Regulatory Commission

OSHA Occupational Safety and Health Agency

RCRA Resource Conservation and Recovery Act

SAFSTOR Safe Storage

SARA Superfund Amendments and Reauthorization Act

Sv/yr sievert(s) per year 


\title{
DRAFT PRINCIPLES, POLICY, AND ACCEPTANCE CRITERIA FOR DECOMMISSIONING OF U.S. DEPARTMENT OF ENERGY CONTAMINATED SURPLUS FACILITIES AND SUMMARY OF INTERNATIONAL DECOMMISSIONING PROGRAMS
}

\author{
B.K. Singh, J. Gillette, and J. Jackson
}

\section{INTRODUCTION}

Many U.S. Department of Energy (DOE) facilities have reached the end of their operating life or no longer have missions. Some of these facilities are contaminated with radioactive and hazardous materials. To protect public health and safety, DOE must ensure that these facilities are cleaned up in a safe and cost-effective manner.

Cleanup of these facilities falls under the general term "decommissioning." The International Atomic Energy Agency (IAEA) defines this term as actions taken to retire the facility from service in a manner that provides adequate protection for the health and safety of the worker, the general public, and the environment (IAEA 1988). As used in this document, the term "decommissioning" means any actions taken to retire a contaminated surplus facility in a manner that provides adequate health and safety protection to the general public, workers, and environment. It includes the following actions, either singly or in combination: deactivation, transfer, decontamination, dismantling, and demolition. The term "facility," as used in this document, is defined as one or more buildings or structures, including equipment, systems, and components, and land dedicated to a common function. Decommissioning actions range from closing the facility, with minimal removal of contaminated material and continuing maintenance and surveillance, to completely removing all residual contamination so that the facility meets unrestricted release requirements.

Decommissioning activities enable the DOE to reuse all or part of a facility for future activities and reduce hazards to the general public and any future work force. As the U.S. Nuclear Regulatory Commission (NRC) states, "decommissioning has many positive environmental impacts such as the return of possibly valuable land to the public domain and the elimination of potential problems associated with increased numbers of radioactively contaminated facilities with a minimal use of resources" (NRC 1988).

The DOE Office of Environment, Health, and Safety has prèpared this document, which consists of decommissioning principles and acceptance criteria, in an attempt to establish a policy that is in agreement with the NRC policy. The purpose of this document is to assist individuals 
involved with decommissioning activities in determining their specific responsibilities as identified in Draft DOE Order 5820.DDD, "Decommissioning of U.S. Department of Energy Contaminated Surplus Facilities" (Appendix A). This document is not intended to provide specific decommissioning methodology. The DOE Decommissioning Handbook and Radiological Control Manual contain specific information on decommissioning and methodology (DOE 1994a,f).

The policies and principles of several international decommissioning programs are also summarized. These programs are from the IAEA, the NRC, and several foreign countries expecting to decommission nuclear facilities. They are included here to demonstrate the different policies that are to be followed throughout the world and to allow the reader to become familiar with the state of the art for environment, safety, and health (ES\&H) aspects of nuclear decommissioning. 


\section{BACKGROUND}

This document consists of five major components:

- ES\&H principles and policies to be followed in the decommissioning of DOE's contaminated surplus facilities (Section 5);

- Acceptance Criteria for the ES\&H requirements relevant to decommissioning (Section 5);

- A summary of selected decommissioning programs throughout the world (Section 6).

- A draft DOE order entitled "Decommissioning of U.S. Department of Energy Contaminated Surplus Facilities" (see Section 4 and Appendix A); and

- Draft decommissioning standards (Appendix B).

The original intent was to prepare each of the components for presentation and discussion at a meeting of decommissioning experts held by the DOE Office of Environment, Safety, and Health and Argonne National Laboratory in September 1994. These experts would provide further insights into decommissioning problems, issues, and concerns that would enhance the value and usefulness of the DOE order. As the DOE shifted its emphasis to new directive systems, however, the utility of new DOE orders was lessened. As a result, the meeting was postponed, and the order remains in draft status.

The ES\&H principles and policies used in preparing the draft order will likely be the basis for any DOE order or similar guidance on decommissioning. This document provides a concise, useful, and referable format for these principles and policies. Providing acceptance criteria as an integral part of a DOE order is a new concept, although it has been used by other regulatory agencies, such as the NRC. This document illustrates the value in providing acceptance criteria along with the requirements and the way DOE can use this concept.

This document also summarizes selected international decommissioning programs. The various policies and principles used in regulating decommissioning activities in these countries were also used as references in establishing the policies and principles that form the basis of the draft DOE order on decommissioning. 


\section{DECOMMISSIONING HISTORY, POLICY, AND PRINCIPLES}

In 1978, when the DOE was created, the DOE Surplus Facilities Management Program was formed to initiate a formal decontamination and decommissioning (D\&D) program. Routine surveillance and maintenance (and sometimes repairs) of aging facilities would continue until decommissioning activities commenced. In 1981, surplus DOE facilities became the responsibility of the Defense D\&D Program and the Office of Nuclear Energy. In 1989, D\&D activities were consolidated into the Office of Environmental Restoration and Waste Management, which is now known as the Office of Environmental Management.

The DOE policy on decommissioning has always been, and continues to be, that program activities will be conducted according to applicable environmental protection regulations. By the early 1990s, DOE guidelines were developed to ensure compliance with the National Environmental Policy Act (NEPA); the Resource Conservation and Recovery Act (RCRA); the Comprehensive Environmental Response, Compensation, and Liability Act (CERCLA); and the Superfund Amendments and Reauthorization Act (SARA). Many of the lessons learned and other valuable information concerning the planning, technology development, and conduct of D\&D operations are shared with other DOE operations offices and other countries to both control costs and better ensure health and safety.

The DOE contaminated surplus facilities shall be decommissioned in a safe, cost-effective manner to ensure that release of and exposure to radioactive and/or hazardous materials comply with federal and state requirements. Components, equipment, and valuable materials shall be recovered and reused, when practical. Radioactive, hazardous, and mixed waste generated from the decommissioning of DOE facilities shall be managed in a manner that ensures protection of the health and safety of the public, the workers, and the environment.

The objectives and policies of the $D \& D$ program have remained reasonably consistent since the DOE was established. These objectives and policies, as stated by the Defense D\&D Program (DOE 1988a), are to:

- Complete decommissioning activities of all surplus contaminated facilities accepted into the Defense D\&D Program inventory in accordance with applicable codes and standards;

- Maintain surplus facilities awaiting decommissioning in a safe, secure condition to minimize potential hazards to the public and the environment;

- Reduce the costs of maintenance, surveillance, and decommissioning; 
- Identify and make available for reuse valuable materials, equipment, facilities, and property designated as surplus;

- Conduct planning and research and development in support of the Defense D\&D Program;

- Provide a decommissioning information center and a facility record/archive center and disseminate decommissioning technology;

- Actively share Defense D\&D Program decommissioning technology developments and project experience with other U.S. government programs and the commercial nuclear industry and thereby contribute to the safety, economy, and speed of all nuclear decommissioning; and

- Participate in appropriate international activities in support of DOE agreements for technology exchange. 


\section{DOE ORDER ON DECOMMISSIONING OF CONTAMINATED SURPLUS FACILITIES}

DOE Order 5820.2A, "Radioactive Waste Management," provides the policy and guidelines for decommissioning DOE radioactively contaminated facilities and is being revised (DOE 1988b, 1994e). Draft DOE Order 5820.DDD, "Decommissioning of U.S. Department of Energy Contaminated Surplus Facilities," has been written as a replacement for Chapter V of DOE Order 5820.2A (DOE 1988b). This draft order (Appendix A) explains that the D\&D process is designed to be functionally equivalent to the cleanup requirements identified by CERCLA and RCRA. The process consists of seven phases (DOE 1994b):

- Transition,

- Project preparation,

- Environmental review,

- Engineering and planning,

- Decommissioning operations,

- Closeout and verification, and

- Postoperations activities.

The draft order was prepared after consideration of several factors:

- The large number of DOE facilities awaiting deactivation, decontamination, and decommissioning;

- The need to address hazardous and chemical contaminants as well as radiological ones;

- The desire to formally incorporate recently promulgated principles into the planning, management, and conduct of decommissioning projects;

- The administrative and operational structure within DOE with respect to the operation, transition, and decommissioning of surplus contaminated facilities; and 
- The need to establish more formal acceptance criteria for decommissioning activities.

Draft DOE Order 5820.DDD requires a formal Decommissioning Plan for each project. Such a plan will ensure that ES\&H considerations are incorporated into each proposed decommissioning project. It will also ensure that DOE policies and principles are incorporated in the planning, management, and conduct of such D\&D projects. Section 5 lists the 10 elements required in the Decommissioning Plan and provides acceptance criteria for DOE approval of these elements and the overall plan.

In addition to these principles, the Assistant Secretary has outlined six strategic goals for the Office of Environmental Management D\&D and remedial action efforts (DOE 1994b):

- Manage and eliminate the urgent risks and threats in the system;

- Provide a safe workplace that is free from fatalities and serious accidents and continually reduce injuries and adverse health effects;

- Change the system so that its management and finances are under control;

- Be more outcome oriented;

- Focus the technology development program on DOE's major environmental management issues while involving the best talent in the DOE and the national (public and private) science and engineering communities; and

- Develop a strong partnership between the DOE and its stakeholders. 


\section{ACCEPTANCE CRITERIA FOR DECOMMISSIONING PLANS}

Any organization responsible for contaminated facilities must ensure that after a facility ceases operation, it is cleaned up in a safe and cost-effective manner and complies with federal and state requirements. The Decommissioning Plan presented in Draft DOE Order 5820.DDD is based primarily on similar plans from the NRC, DOE, and IAEA. It also reflects DOE policies and principles on decommissioning projects, as noted in Section 3.

Established principles include planning, conducting, and closing out D\&D projects in accordance with applicable codes and standards that address policy, regulatory, safety, and cost containment requirements. The reuse and recycling of surplus equipment and materials is now a fundamental principle in many waste management and D\&D policies. Including the public in the decision-making process is a relatively new principle. Strong program and project management is emphasized to ensure that other principles, such as technology exchange, are followed. Focusing technical resources on the technical, safety, and cost issues associated with D\&D projects is another important principle.

Ten elements are required in a Decommissioning Plan:

- Facility Description and History (Part A). A description and history of the facility.

- Characterization (Part B). Physical, chemical, hazardous, and radiological characterization data or references to such data.

- Decommissioning Alternative (Part C). A summary evaluation of decommissioning alternatives for the facility and identification of the preferred alternative.

- Environmental Review Process and Cleanup Criteria (Part D). Plans for meeting requirements of the environmental review process (NEPA, RCRA, CERCLA, and SARA) and all necessary permits; cleanup criteria to be used and applicable standards on which criteria are based.

- Decommissioning Activities (Part E). A discussion of the scope of work required to meet the objectives of the preferred decommissioning alternative.

- Organization and Program Management (Part F). A description of the organization responsible for managing the decommissioning project, including 
the plan for training, quality assurance, security (including nuclear safeguards), project controls, and subcontractor and procurement activities.

- Health and Safety Program (Part G). A detailed discussion of the health and safety program, describing the Occupational Safety and Health Agency (OSHA) and health physics programs, including as-low-as-reasonablyachievable (ALARA) implementation and projections of occupational radiological and chemical exposure; all applicable safety requirements; and measures to meet those requirements.

- Waste Management (Part $\mathrm{H})$. A discussion of the waste management program, including processes and systems to be used for processing and disposing of wastes generated during the decommissioning activities, waste minimization activities, and estimates of the quantities of waste generated.

- Final Survey (Part I). Final survey requirements that detail the way the regulatory and cleanup criteria objectives will be verified and the procedure for conducting final surveys, including instrumentation and the recording of survey results; and provisions for a final radiological and chemical survey report and an independent verification report.

- Project Closeout (Part J). Documents and records required for the data package assembled at the completion of the project: project final report, record of completion, certification docket, and appropriate public notices for facilities being released to the public.

The following sections describe the information that must be included in each of the 10 Decommissioning Plan elements and the acceptance criteria. The acceptance criteria are based primarily on existing DOE orders, although some additional requirements, such as draft standards, are identified. Appendix B briefly describes the draft standards presented in the acceptance criteria.

\subsection{FACILITY DESCRIPTION AND HISTORY}

\subsubsection{Description}

The description of the facility shall include its operating history and current status. The operations description shall include the scope of past and present activities at the facility. The description shall include the size of the facility, any applicable structures, and important site 
characteristics, such as disposal sites or ponds. Maps, facility drawings, and diagrams (and any modifications of radiological work sites) shall be included.

\subsubsection{Acceptance Criteria}

The Facility Description and History part must be consistent with the scope and content of DOE Order 5480.23, "Nuclear Safety Analysis Reports," which includes "Facility description and operation, including design of principal structures, components, all systems, engineered safety features and processes" (DOE 1994e).

The Facility Description and History part must be consistent with the requirements of DOE Order 4300.1C, "Real Property Management," Chapter II, Disposal of Real and Related Personal Property, (1)(g)(1-22), which requires a memorandum addressing the following: general description; location; cost; nature of the real estate; brief history; mineral rights; impact on natural resource conservation programs; existence of facilities of cultural and historical significance; environmental and economic impact; number of personnel affected; permits; restrictions; project schedule; photographs; maps; certification that DOE Order 5400.5, "Radiation Protection of the Public and the Environment," Section 120(h) of CERCLA, and other federal, state, or local regulations for residual radioactive material and other hazardous substances have been met; identification of any underground storage tanks; and approval requirements (DOE 1992i, 1993c).

The requirements of the forthcoming DOE Standard DOE-STD-XYZ-6, "Deactivation of Contaminated DOE Facilities," when approved, will serve as acceptance criteria for the Facility Description and History part. This standard will provide guidance on the procedures for deactivating surplus facilities.

\subsection{CHARACTERIZATION}

\subsubsection{Description}

The Decommissioning Plan shall include historical information on operational occurrences that could affect decommissioning alternatives, procedures, or safety. This information shall include a list of locations at the facility where any work with radioactive, hazardous, or chemical materials was ever performed; the material involved; a description of the operations performed; and typical radiation and contamination levels during those operations. Reports on occurrences such as spills, releases, or other accidents that resulted in significant residual contamination shall also be included. 
Radiation levels of contaminated systems, structures, and components to be decommissioned shall be identified. Although complete information may not be available at the time the Decommissioning Plan is submitted, radiation sources that form the basis for radiation protection shall be described by either measurement or calculation. This information shall be updated as additional radiation surveys are conducted. Radiation sources shall be described by dose rate and location; major sources of radioactivity shall be identified on facility layout drawings.

Hazardous and chemical materials shall be characterized in a manner similar to that for radioactive materials, which can be done through the existing environmental surveillance programs. These programs detail facility characteristics; applicable regulations; hazard potential; quantities and concentrations of materials released; the extent and use of affected air, land, and water; and specific local public interests or concerns.

\subsubsection{Acceptance Criteria}

The Characterization part must meet the following requirements of DOE Order 5400.1C, "General Environmental Protection Program," Attachment II, Notification and Reports, (8)(b\&c), (10), and (11) (DOE 1990b): a brief description of each of the media sampled (radioactive or nonradioactive); type and frequency of sampling; methods of analysis; a map showing the location of monitoring stations and sampling points; an assessment of the potential radiation exposures to the public; the modeling and calculation methodology used in the dose assessment; and a comparison of results with applicable standards and relevant parameters.

The Characterization part must meet the requirements of DOE Order 5634.1B, "Facility Approvals, Security Surveys, and Nuclear Materials Surveys," Chapter V, Nuclear Materials Surveys, (3)(a)(1) (DOE 1992c). A report on the results of a survey of nuclear materials control and accountability must be prepared that includes such items as a statement of the survey scope and period of coverage and a statement regarding the facility's function and scope of operations related to nuclear, hazardous, and chemical materials.

The Characterization part must meet the requirements of DOE Order 5820.2A, "Radioactive Waste Management," Chapter I, High-Level Waste, (3)(b)(1)(a) (DOE 1988b). Liquid and solidified high-level waste must be characterized according to radiation protection requirements to determine its hazardous components. The characterization must reflect knowledge of waste-generating processes, laboratory testing results, or the results of periodic sampling and analysis.

The Characterization part must meet the requirements of DOE Order 5820.2A, "Radioactive Waste Management," Chapter II, Management of Transuranic Waste, (3)(a)(1) and (3)(I)(2) (DOE $1988 \mathrm{~b})$. These requirements apply to any material that is known or suspected to be contaminated with transuranic radionuclides. Each waste site must be characterized with information on the types 
and quantities of radioactive, hazardous, and chemical contaminants. This information will be verified by appropriate sampling, analysis, and monitoring techniques.

The Characterization part must meet the requirements of DOE Order 5820.2A, "Radioactive Waste Management," Chapter III, Management of Low-Level Waste, (3)(d)(1) (DOE 1988b). The requirements characterize low-level waste with sufficient accuracy to permit proper segregation, treatment, storage, and disposal. This characterization will ensure that the actual physical and chemical characteristics and major radionuclide content are recorded and known during all stages of the waste management process.

The Characterization part must meet the record-keeping requirements of the DOE Radiological Control Manual, Chapter 7, Radiological Records (DOE 1994f).

The requirements of the forthcoming DOE Standard DOE-STD-XYZ-2, "Characterization for Decontamination and Decommissioning," when approved, will serve as acceptance criteria for the Characterization part. This standard will provide guidance on conducting surveys for radiological and hazardous substance contamination in connection with decommissioning activities at DOE facilities.

\subsection{DECOMMISSIONING ALTERNATIVES}

\subsubsection{Description}

The summary of decommissioning alternatives shall describe the alternatives as they apply to the specific facilities considered in the Decommissioning Plan. Attributes used to select the preferred alternative should be noted, along with the specific features or characteristics of each alternative.

The following are three major decommissioning alternatives:

- Storage with surveillance and monitoring. This alternative consists of retaining the first contamination barrier, but permanently blocking and sealing the mechanical systems. The outermost containment manages the remaining hazard with appropriate atmospheric and access controls. This alternative corresponds to IAEA stage 1 and the NRC SAFSTOR alternative (Appendix A).

- Restricted site use. This alternative consists of reducing the first contamination barrier to a minimum, with possible physical reinforcement. 
The facility will be decontaminated to acceptable levels, and safety systems will be removed if they are no longer required. Periodic spot checks should be continued, but surveillance and monitoring requirements can be eased. This alternative corresponds to IAEA stage 2 and the NRC ENTOMB alternative.

- Unrestricted site use. This alternative consists of removing all contaminated materials, equipment, and facility components if they cannot be fully decontaminated. The facility is released without restriction, and no further surveillance, inspections, or tests are required. This alternative corresponds to IAEA stage 3 and the NRC DECON alternative.

Decommissioning can be phased over a period of time if the facility and site land-use requirements allow. For example, all major decommissioning alternatives can be incorporated into one long-term plan. Technology alternatives for each alternative and phase of the decommissioning project will be addressed in the engineering and project plans.

\subsubsection{Acceptance Criteria}

The Decommissioning Alternatives part must meet the requirements of DOE Order 4300.1C, "Real Property Management" (DOE 1992i). This order provides guidance on criteria for the disposal of DOE property that may occur as a result of decommissioning.

The requirements of the forthcoming DOE Standard DOE-STD-XYZ-3, "Decommissioning Alternatives," when approved, will serve as acceptance criteria for the Decommissioning Alternatives part. This standard will provide guidance on decommissioning alternatives.

\subsection{ENVIRONMENTAL REVIEW PROCESS AND CLEANUP CRITERIA}

\subsubsection{Description}

The Decommissioning Plan shall discuss the actions necessary for compliance with applicable environmental laws and regulations. These actions shall be identified, and the mechanisms for incorporating findings of various phases of the decommissioning project into the plans and reviews of subsequent phases shall be discussed.

Cleanup criteria for facilities shall be established that are consistent with the future use of the facility or site. When unrestricted site use is the objective, the cleanup goal shall be to reduce the radionuclide concentrations to levels indistinguishable from background. A value of $15 \mathrm{mrem} / \mathrm{yr}$ 
shall be regarded as the limit for unrestricted use. With controls in place, this $15 \mathrm{mrem} / \mathrm{yr}$ value shall also serve as the maximum total effective dose equivalent for restricted use (NRC 1994). When facilities are to be recycled or reused, the cleanup criteria shall be established according to existing DOE orders, good practices, and ALARA considerations.

\subsubsection{Acceptance Criteria}

The Environmental Review Process and Cleanup Criteria part must meet the appropriate review requirements of DOE Order 5400.4, "Comprehensive Environmental Response, Compensation, and Liability Act Requirements," and DOE Order 5440.1E, "NEPA Compliance Program" (DOE 1989, 1992e). The Environmental Review Process and Cleanup Criteria part must meet the cleanup criteria of DOE Order 5400.5, "Radiation Protection of the Public and the Environment" (DOE 1993c).

In the Environmental Review Process and Cleanup Criteria part, the anticipated residual contamination level must be below $15 \mathrm{mrem} / \mathrm{yr}$ for radioactive contaminants or below the specific contamination levels set by various regulatory agencies for individual hazardous contaminants (NRC 1994). The Decommissioning Plan must include a final survey plan that specifies actions and measurements to confirm compliance with the appropriate cleanup criteria.

The requirements of the forthcoming DOE Standard DOE-STD-XYZ-5, "Criteria for the Unrestricted Release of Sites, Facilities, Materials, and Equipment," when approved, will serve as acceptance criteria for the Environmental Review Process and Cleanup Criteria part. This standard will provide guidance on meeting the criteria for the unrestricted release of sites, facilities, materials and equipment.

\subsection{DECOMMISSIONING ACTIVITIES}

\subsubsection{Description}

The decommissioning objective, the proposed activities to achieve this objective, and the rationale for selecting particular decommissioning methods shall be described. The Decommissioning Plan shall discuss the development of project plans, engineering designs, technology alternatives, and cost and schedule estimates.

All activities associated with the decommissioning project shall be described briefly. These activities include those related to the preparation and maintenance of the facility during the various phases of the decommissioning project. The relationships among the activities shall be identified and 
explained. Where pertinent, the schedules for accomplishing interrelated activities shall be delineated. Activities with safety implications shall specifically be noted. An estimate of the exposure shall be provided for activities that involve human exposure to radiation or hazardous contaminants or materials. ALARA principles shall be considered in the planning of these activities.

This part shall discuss accidents that could significantly affect occupational or public health and safety during decommissioning (e.g., criticality). Reference can be made to potential accidents during plant operations or maintenance, if appropriate.

This part shall list federal, state, and local laws and regulations applicable to the proposed decommissioning activity. Where environmental reviews are required for compliance, the Decommissioning Plan shall note how such reviews will be accomplished within the proposed schedule. The information to be reviewed, the specific activities for providing such information, and the person who will conduct these activities shall be noted. The schedule for environmental reviews shall be an integral part of the overall project schedules and milestones.

A cost estimate for the decommissioning project shall be provided. Cost and schedule information shall be presented in accordance with applicable DOE orders. Assumptions and regulatory drivers used in estimating cost and schedule shall be provided. The process for making necessary changes in the cost and schedule shall also be described.

\subsubsection{Acceptance Criteria}

The acceptance criteria for the Decommissioning Activities are divided into six sections.

\subsubsection{Radiation Doses}

The Decommissioning Activities part must meet the appropriate requirements of the following DOE orders:

- DOE Order 5484.1, "Environmental Protection, Safety, and Health Protection Information Reporting Requirements," Attachment 8, Revised Radiation Exposure Information Reporting System U.S. Department of Energy Annual Radiation Dose Summary (DOE 1990a);

- DOE Order 5000.3B, "Occurrence Reporting and Processing of Information," Attachment 1, Categorization of Reportable Occurrences, Group 4, Personnel Radiation Protection (DOE 1993b); 
- DOE Order 5400.5 "Radiation Protection of the Public and the Environment," Chapter III, Derived Concentration Guides for Air and Water (DOE 1993c);

- DOE Order 5480.23, "Nuclear Safety Analysis Reports," Attachment 1, Interim Guidance for DOE Order 5480.23 Safety Analysis Report (SAR), $(4)(f)(3)(d)(9)(D O E ~ 1994 c)$; and

- DOE Order 5480.11, "Radiation Protection for Occupational Workers" (9) (DOE 1992h).

\subsubsection{Environmental Review}

The Decommissioning Activities part must meet the requirements of DOE Order 4700.1, "Project Management System," Chapter II, Strategic Planning, Project Planning and Budgeting, Part F, Environmental Planning and Review, (2)(b)(1-5) and (4)(c)(1) (DOE 1992g). This order requires "phased compliance" characterized by a comprehensive review of all applicable federal, state, and local policies, programs, and regulations; identification of all requirements integrated into an efficient time schedule, including critical paths; and coordination of various environmental reviews (including early reviews and requirements identified in the NEPA) with appropriate phases of project development.

The Decommissioning Activities part must include the detailed schedule required in DOE Order 4700.1 "Project Management System," Attachment V-9, Conceptual Design Reports, (3)(I)(4), for compliance with NEPA and other environmental review requirements (DOE 1992g).

The Decommissioning Activities part must meet the review requirements of DOE Order 5440.1E, "National Environmental Policy Act" (DOE 1992e).

\subsubsection{Transportation}

The Decommissioning Activities part must meet the appropriate transportation guidelines and regulations cited in the following DOE orders:

- DOE Order 1540.1A, "Materials Transportation and Traffic Management" (DOE 1992d);

- DOE Order 5820.2A, "Radioactive Waste Management," Chapter II, Management of Transuranic Waste, (f) (DOE 1988b); 
- DOE Order 5480.3, "Safety Requirements for the Packaging and Transportation of Hazardous Materials, Hazardous Substances, and Hazardous Wastes" (DOE 1985);

- DOE Order 1540.3A, "Base Technology for Radioactive Material Transportation Packaging Systems" (DOE 1992a); and

- DOE Order 5480.4, "Environmental Protection, Safety, and Health Protection Standards," Attachment 1, Mandatory ES\&H Standards (Statutory Requirements), and Attachment 2, Mandatory ES\&H Standards (Policy Requirements) (DOE 1993a).

\subsubsection{Accident Risk Assessment}

The Decommissioning Activities part must consider final decommissioning in the planning documents required in DOE Order 5480.6, "Safety of Department of Energy-Owned Nuclear Reactors," (8)(j) (DOE 1986). The facility shall be radiologically characterized, and a safety assessment shall be conducted to determine the existence of hazardous or radioactive material and nuclear fuel. Arrangements shall be made to ensure adequate surveillance and maintenance of the facility during any indefinite standby period.

The Decommissioning Activities part must meet the requirements of DOE Order 5480.23, "Nuclear Safety Analysis Reports," (8)(b)(3)(k) (DOE 1994c). These requirements include an analysis of normal, abnormal, and accident conditions, including design-basis accidents; risk assessments; consideration of natural and man-made external events; assessment of contributory and causal events, mechanisms, and phenomena; and evaluation of the need for an analysis of beyonddesign-basis accidents.

The Decommissioning Activities part must meet the applicable requirements of DOE Order 4700.1, "Project Management System," Chapter V, Procedures for Construction Management, (2)(1) (DOE 1992g). These requirements establish a comprehensive health and safety program for all DOE construction projects. The goals of this program are to protect DOE employees, contractor employees, and the general public from hazards; to protect property from damage; and to prevent delay or interruption in DOE programs caused by accidents and fires in connection with construction activities. Safety requirements must be considered early in the planning phase of a project to ensure that they are included in all plans, studies, schedules, and cost estimates.

The Decommissioning Activities part must meet the requirements of DOE Order 5500.3A, "Planning and Preparedness for Operational Emergencies," (9)(d) (DOE 1992f). These requirements include preparing a hazard assessment that will provide the technical basis for emergency 
management programs. The extent of the program corresponds to the type and scope of hazards present and the potential consequences of accidents or events. A hazards assessment includes identification of any hazards and targets unique to a facility, analyses of potential accidents or events, and evaluation of potential accident or event consequences.

\subsubsection{Worker and Public Safety}

The Decommissioning Activities part must meet the applicable requirements for worker and public safety in DOE Order 5480.22, "Technical Safety Requirements," Attachment 1, Background, (6), and DOE Order 5480.11, "Radiation Protection for Occupational Workers" (DOE 1992h,j).

\subsubsection{Schedule}

The Decommissioning Activities part must demonstrate that the schedule of the decommissioning activities will be completed as soon as reasonably achievable according to DOEapproved milestones.

\subsection{ORGANIZATION AND PROGRAM MANAGEMENT}

\subsubsection{Description}

A description of the organization and decommissioning responsibilities with respect to the overall decommissioning project shall be provided, and specific functions shall be identified. The lines of authority and responsibilities shall be indicated. The education, training, and experience requirements of personnel shall be described. The person with ultimate on-site authority shall be designated by position. The decommissioning organization shall include a means of monitoring the decommissioning operation to ensure that it is being performed safely. Personnel to review and audit major decommissioning operations that deal with special nuclear material, radioactive material, radiological controls, review procedures, records, reportable occurrences, and changes shall be identified. Procedures for relaying the conclusions of such reviews and audits shall be specified.

This part shall describe the training program for all personnel associated with the decommissioning project and the qualifications of the trainers. The description shall include the scope of training in decontamination and other decommissioning activities, health physics, and the use and maintenance of surveillance and monitoring equipment. A system for maintaining training records shall be described. 
The quality assurance program to be established and executed during decommissioning shall be described. Equipment (e.g., plasma torches, portable ventilation, and shielding) and procedures subject to the quality controls and audits shall be noted. The Decommissioning Plan shall include a management commitment to conduct decommissioning activities in accordance with written and approved procedures (i.e., Radiological Control Manual and Decontamination and Decommissioning Handbook). The control system that ensures that procedures are prepared, reviewed, revised, approved, and implemented shall be described.

Some or all decommissioning activities may be done by subcontractors. However, DOE maintains responsibility for safety during decommissioning. Activities to be performed under subcontractor licenses shall be identified. The scope of work, the contractor qualifications to perform such work, and administrative controls to be used to ensure adequate health and safety protection shall be described.

\subsubsection{Acceptance Criteria}

The Organization and Program Management part must meet the appropriate qualification, training, and experience requirements identified in DOE Order 5480.20, "Personnel Selection, Qualification, Training, and Staffing Requirements at DOE Reactor and Non-Reactor Nuclear Facilities," and DOE Order 5700.6C, "Quality Assurance," Attachment 1, Guidance for Developing and Implementing Quality Assurance Programs, (II)(A)(E) (DOE 1991, 1994d).

The Organization and Program Management part must meet the applicable quality assurance, personnel training, and qualification requirements in DOE Order $5700.6 \mathrm{C}$, "Quality Assurance," Attachment 1, Guidance for Developing and Implementing Quality Assurance Programs, (II)(A)(E), and DOE Order 4700.1, "Project Management System," Attachment III, Part D - Quality Assurance (DOE 1991, 1992g).

The Organization and Program Management part must meet the applicable requirements in the Radiological Control Manual, Chapter 6, Training and Qualifications (DOE 1994f).

The Organization and Program Management part must meet the appropriate requirements for management reviews in DOE Order 5700.6C, "Quality Assurance," Attachment 1, Guidance for Developing and Implementing Quality Assurance Programs, (II)(A)(1) (DOE 1991).

The Organization and Program Management part may document an acceptable training program by referring to previously approved submittals and committing to maintain the referenced program during decommissioning. Any changes to the documented program must be described in the Decommissioning Plan. If an approved program is not currently in place, the Radiological 
Control Manual will be used as guidance to determine compliance with the forthcoming 10 CFR Part 835, "Occupational Radiation Protection: Final Rule."

\subsection{HEALTH AND SAFETY PROGRAM}

\subsubsection{Description}

The Health and Safety Program part shall describe the methods used to protect workers and the environment against radioactive, hazardous, and chemical contaminants during decommissioning.

The Decommissioning Plan may demonstrate the existence of an acceptable ALARA program by referring to previously approved submittals and committing to maintain the referenced program during decommissioning. The submittals and the DOE approval document shall be included as an attachment to the Decommissioning Plan. Any changes to the documented ALARA program shall be described in the Decommissioning Plan. The Decommissioning Plan shall include an occupational exposure estimate, in person-rems, for each major decommissioning activity.

The criteria for selecting equipment and instrumentation for performing radiation and contamination surveys and personnel monitoring shall be provided. The types of instruments to be used and their purpose (e.g., personnel monitoring, radiation surveys) shall be described. In addition, the use, storage, calibration, testing, and maintenance of these instruments shall be described.

The methods, frequency, and procedures for effluent monitoring, radiation surveys, and personnel monitoring (including internal and external dosimetry equipment) shall be described. The anticipated use of respiratory protection shall be explained. Methods for contamination control shall be described.

If appropriate, changes may be made to an existing program for applicability to decommissioning. However, the Decommissioning Plan shall clearly indicate the contents of the existing program and present any additional information required.

The health physics and hazardous materials programs shall identify potential sources of radiation or hazardous contamination exposure to workers or the public that are generated by decommissioning activities. Methods for control of these potential sources shall be specified.

The methodology and assumptions used in making projections of occupational exposure shall be presented. The policy and procedures for keeping individual and collective occupational radiation exposure ALARA during decommissioning shall be identified. The health physics program 
to be in effect during decommissioning shall be described (e.g., a work activity control program to minimize worker exposure, a program for controlling sources and minimizing spread of contamination, or a respiratory protection program to determine hazards and provide appropriate equipment). Persons responsible for radiation protection and maintaining ALARA occupational exposure during decommissioning shall be designated by position. A safety program detailing the way all applicable OSHA requirements will be implemented shall be described.

\subsubsection{Acceptance Criteria}

The Health and Safety part must meet the public dose limits and the ALARA program set forth in DOE Order 5400.5, "Radiation Protection of the Public and the Environment," Chapter 1, General, (3-4), and Chapter 2, Requirements for Radiation Protection of the Public and the Environment, (1-2) and (6), and DOE Order 5480.19, "Conduct of Operations Requirements for DOE Facilities," Chapter II, Shift Routines and Operating Practices, (c)(5) (DOE 1992b, 1993c).

The Health and Safety part must meet the applicable radiation doses, contamination control, and monitoring requirements in DOE Order 5480.11, "Radiation Protection for Occupational Workers," particularly (9)(g) (DOE 1992h).

The Health and Safety part must meet the requirements that apply to effluent monitoring in DOE Order 5400.1, "General Environmental Protection Program," Chapter IV, Environmental Monitoring (DOE 1990b).

The Health and Safety part must meet the requirements in the Radiological Control Manual, Chapter 2, Radiological Standards, Parts 1 and 2, and Chapter 5, Radiological Health Support Operations, Parts 5 and 6 (DOE 1994f).

Compliance with the forthcoming 10 CFR Part 835 may be demonstrated by following the appropriate requirements in the Radiological Control Manual (DOE 1994f).

\subsection{WASTE MANAGEMENT}

\subsubsection{Description}

Assumptions and methodologies used in estimating waste quantities shall be presented. The estimates shall include a detailed characterization of generated wastes and projected volumes; radionuclide and hazardous concentrations; and waste forms and classification. These estimates shall 
be integrated into the waste minimization plan. The objectives of the waste minimization plan shall, in turn, be incorporated into the Decommissioning Plan and the corresponding procedures.

Waste treatment systems, including concentrations of contaminants and volumes of wastes to be treated, shall be described. It shall be indicated whether existing systems will be used or new systems will be installed.

Procedures, processes, and systems to be used for handling, storing, and disposing of waste shall be summarized. The issues of compliance with disposal restrictions and meeting waste acceptance criteria shall be addressed. If radioactive wastes are to be temporarily stored on-site, the quantities of waste, expected length of storage, location of storage areas, radiation levels at access points, and manner in which positive control will be maintained shall be described.

\subsubsection{Acceptance Criteria}

The Waste Management part must meet the appropriate requirements in the following chapters of DOE Order 5820.2A, "Radioactive Waste Management": Chapter I, High-Level Waste; Chapter II, Management of Transuranic Waste; Chapter III, Management of Low-Level Waste; and Chapter IV, Management of Waste Containing Naturally Occurring and Accelerator Produced Radioactive Material (DOE 1988b).

The Waste Management part must meet the requirements set forth in DOE Order 5400.1, "General Environmental Protection Program," Chapter III, Environmental Protection Program Plans, (4)(b) (DOE 1990b). These requirements include a waste minimization program that will identify goals for minimizing the volume and toxicity of all generated wastes. The proposed methods of treatment, storage, and disposal that minimize waste and are technically and economically practicable shall be reported, as appropriate. Waste minimization plans required by specific legislation, such as RCRA, shall be included.

The Waste Management part must meet the requirements of DOE Order 5400.5, "Radiation Protection of the Public and the Environment," Chapter I, General, (6), and Chapter II, Requirements for Radiation Protection of the Public and the Environment (DOE 1993c). These requirements are intended to prevent the buildup of low-level radioactive waste contamination in soils and groundwater and the spread of contamination from burial trenches and pits.

The Waste Management part must meet the requirements in the following chapters of DOE Order 5820.2A, "Radioactive Waste Management": waste classification requirements in Chapters I-III; disposal requirements in Chapter III, Management of Low-Level Waste, (3)(i); and waste type requirements in Chapter I, High-Level Waste, $(3)(b)(2)(e)$, and Chapter VI, Waste Management Plan Outline, (3)(c)(1)(b) (DOE 1988b). 


\subsection{FINAL SURVEY}

\subsubsection{Description}

The Final Survey part shall describe the final radiation or chemical survey. The final survey shall provide the basis for verifying that the facility and the contiguous adjacent environs meet the criteria for unrestricted or restricted use, as appropriate.

The description shall discuss the proposed method for ensuring that sufficient data will be collected for a meaningful statistical survey and that all pertinent structures, systems, components, and equipment are included. Other discussions shall address (1) the type and operating conditions of instruments to be used; (2) methods for obtaining and analyzing data; (3) information on preoperational survey results and other data on background contaminants; and (4) methods for auditing and verifying data.

The Final Survey part shall demonstrate that a reasonable effort has been made to eliminate residual contamination. The radiation and contamination levels expected upon release of the facility should be described explicitly, and a justification for any deviations from existing or accepted guidance shall be provided.

\subsubsection{Acceptance Criteria}

The Final Survey part must meet the intent of the objectives set forth in the Radiological Control Manual, Chapter 5, Radiological Health Support Operations, Part 5, and the requirements of 10 CFR Part 835, “Occupational Radiation Protection: Final Rule” (DOE 1994f).

The Final Survey part must meet the applicable requirements of the forthcoming DOE Standard DOE-STD-XYZ-4, "Criteria for the Unrestricted Release of Sites, Facilities, Materials and Equipment." This standard, when approved, will provide guidance on meeting the criteria for the unrestricted release of sites, facilities, materials, and equipment.

\subsection{PROJECT CLOSEOUT}

\subsubsection{Description}

The Project Closeout part will outline the documents needed for final closeout of the project, and the release and final transfer of the facility, if applicable. The project data package shall 
consist of the record of completion, the final survey report, the final project report, an independent verification survey report, a certification docket, and appropriate public notices for facilities being released for public use. The project data package shall be retained permanently in the field organization archive.

\subsubsection{Acceptance Criteria}

The Project Closeout part must meet the record of completion requirements in DOE Order 4700.1, "Project Management System," Attachment III-4, Example of a Comprehensive Test Program, (4)(b)(1)(c) (DOE 1992g).

The Project Closeout part must meet the applicable radiological survey requirements in the Radiological Control Manual, Chapter 7, Radiological Records, Part 5 (DOE 1994f). 


\section{SUMMARY OF SELECTED INTERNATIONAL DECOMMISSIONING PROGRAMS}

This section presents brief summaries of selected decommissioning programs of various organizations and countries. The summaries cover (1) decommissioning strategy, (2) regulations, and (3) financial provisions. These decommissioning programs may help define and provide a basis for the policies and principles used in decommissioning DOE contaminated surplus facilities. These programs deal specifically with radioactive contaminants, whereas the DOE decommissioning program must also address hazardous and chemical contaminants. Therefore, the programs discussed here may be used as a basis for defining the DOE decommissioning program, but adjustments and additions must be made to incorporate policies and principles for hazardous and chemical contaminants.

\subsection{INTERNATIONAL ATOMIC ENERGY AGENCY}

The IAEA defines three decommissioning stages on the basis of two parameters (IAEA 1983): (1) the physical state of the facility and its equipment and (2) surveillance, inspections, and tests necessitated by that state. The three decommissioning stages are as follows:

- Stage 1 (Storage and Surveillance). Retain the first contamination barrier, but permanently block and seal the mechanical systems. The containment building is kept in an appropriate state for the remaining hazard with adequate atmospheric and access controls, including surveillance and monitoring.

- Stage 2 (Restricted Site Use). Reduce the first contamination barrier to a minimum size with possible reinforcement by physical means. The facility is decontaminated to acceptable levels, and safety systems can be removed if they are no longer required. Periodic spot checks should be continued, but extensive surveillance and monitoring can be relaxed.

- Stage 3 (Unrestricted Site Use). Remove all contaminated materials, equipment, and facility components if they cannot be fully decontaminated. The facility is released without restrictions, and no further surveillance, inspections, or tests are required.

While it is possible to go from stage 1 to stage 2 or 3 , it is more common to select one stage as the final state for the facility and to direct decommissioning activities toward that end. 
The IAEA has outlined eight considerations that influence the selection of the appropriate decommissioning stage for a given facility:

- National nuclear strategy, including waste-handling policy;

- Condition of the facility from a safety point of view;

- Owner's interest, including planned use of site;

- Availability of decommissioning technology;

- Postoperational cost;

- Social considerations;

- Availability of funds; and

- Optimization of decommissioning plans.

\subsection{U.S. NUCLEAR REGULATORY COMMISSION}

The NRC provides regulatory oversight of facilities owned or operated by its licensees. Actions taken by the licensees to decommission those facilities are included in the regulatory purview. As defined by the NRC, decommissioning activities begin when the licensee decides to terminate licensed activities and continues until the licensee can demonstrate that all facilities have been properly decontaminated to acceptable levels.

The NRC has outlined four D\&D alternatives:

- No Action: Involves little or no physical decontamination or dismantlement of the facility and only those surveillance and monitoring activities required by the NRC license. The NRC has stated that this option is "not a viable decommissioning alternative" (NRC 1988).

- DECON: Remove equipment, structures, and portions of the facility that contain radioactive contaminants or are decontaminated to a level that permits the property to be released for unrestricted use shortly after operations cease. 
- SAFSTOR: Maintain the facility in a condition that allows it to be stored safely and subsequently decontaminated (i.e., deferred decontamination) to levels that permit release for unrestricted use.

- ENTOMB: Encase radioactive contaminants in a structurally long-lived material, such as concrete. The entombed structure is appropriately maintained, and continued surveillance is carried out until radioactivity decays to a level that would permit release of the property for unrestricted use (NRC 1988).

\subsection{BELGIUM}

\subsubsection{Decommissioning Strategy}

No formal decommissioning strategy exists for nuclear facilities in Belgium (Nuclear Energy Agency 1986, 1991; Pflugard 1990). All commercial reactors are running with high availability. Major dismantling is likely to be deferred until 2025 (approximately 30 years).

\subsubsection{Regulations}

No specific legislation concerning decommissioning activities exists for nuclear facilities in Belgium. Such activities are covered by the general regulations governing nuclear activities. The exemption level and criteria for decommissioning wastes are not generally defined.

\subsubsection{Financial Provisions}

Decommissioning costs are covered by an internal fund required by the electricityproducing company. Funds are raised through annual contributions during a plant's lifetime (assumed to be 20 years). 


\subsection{CANADA}

\subsubsection{Decommissioning Strategy}

Atomic Energy of Canada Limited (AECL) has developed a three-phase preferred decommissioning strategy for nuclear power stations (IAEA 1983; Kato 1992; Jayawardene and Armstrong 1986; Nair et al. 1986). The first phase consists of placing the station into a "static state," which is a variant of IAEA's stage 1, requiring minimum surveillance. The second phase consists of maintaining the station in a dormant state for a prolonged time, up to 100 years. The third phase consists of completing the decommissioning to restore the nuclear site to its original condition for unrestricted use.

The static state in which Canadian plants are to be placed during their dormancy period is only slightly different from IAEA stage 1 . The buildings surrounding the reactor, such as the service building and the turbine hall, may be decontaminated, and their structures, including internal components and systems, may be partially dismantled for alternate use. In addition, the reactor building containment ventilation system, located in the service building, is reduced to its simplest configuration for intermittent use only when ventilation is required in the normally sealed reactor building. All plant surveillance is performed remotely; no resident personnel are required. Only periodic or intermittent inspection requiring human intervention is needed.

The dormancy period of Canadian nuclear power stations is determined not only by the decay of the radioactive out-of-core components, but also by the ability of the buildings to resist degradation and thus maintain containment. As the slow deterioration of such solidly built structures is readily visible, a simple maintenance program ensures that the integrity of the containment is retained for at least 50 years after the plant has been retired from service.

No permanent disposal facilities for commercially produced low-, medium-, and high-level radioactive waste are available in Canada. However, AECL is in the process of obtaining a license to construct an intrusion-resistant underground structure for permanent storage of low-level waste produced by research institutions, hospitals, and other Canadian radioisotope-using clients of Nordion (formerly the Radiochemical Company of AECL). Currently, the low- and medium-level wastes generated by decommissioning projects are stored on-site. Over the past 10 years, AECL has developed a deep geological disposal concept based on the encapsulation of fuel bundles in titanium containers that are buried deep in granite formations in the Canadian shield for high-level waste, particularly spent fuel. It is expected that no high-level radioactive waste repository will be operating in Canada before 2025. 


\subsubsection{Regulations}

The Canadian policy on decommissioning of nuclear facilities, as defined in the Atomic Energy Control Act, is stated and controlled by a federal government agency, the Atomic Energy Control Board, in a regulatory document. This regulatory document requires that all nuclear facilities be decommissioned satisfactorily at the end of their useful lives in the interest of health, safety, security, and protection of the environment. It also makes the facility owner responsible for demonstrating the technical feasibility and financial capability of decommissioning without imposing specific guidelines. The nuclear plant owner is also required to develop a decommissioning plan from the moment of the plant's inception through actual decommissioning. This plan is subject to ALARA considerations during the operating life of the facility and the approval of the regulatory authority. The authority maintains a flexible outlook on the approval process to incorporate the latest technological advances in decommissioning. The maximum regulatory limits for public dose from a nuclear facility is $5 \times 10^{-3} \mathrm{~Sv} / \mathrm{yr}(500 \mathrm{mrem} / \mathrm{yr})$, and the dose received by an individual must be less than $1 \%$ of this limit.

\subsubsection{Financial Provisions}

Facility owners and operators are responsible for decommissioning their facilities through any means, provided they comply with the pertinent national nuclear objectives, requirements, and performance standards as established by the Atomic Energy Control Board.

\subsection{FINLAND}

\subsubsection{Decommissioning Strategy}

Decommissioning is not a separate question in Finland; it is considered a component of nuclear waste management (Nuclear Energy Agency 1986, 1991; Lamberg 1988). Decommissioning waste is placed into final storage in the same way as the operations waste is. The IAEA defined stage 3 as the target of decommissioning after a cooling time of two to five years (as soon as practical). The plant area is reserved for energy production purposes and will not be released for public use. 


\subsubsection{Regulations}

No specific decommissioning regulations have been formulated; therefore, the general provisions for nuclear work apply. No criteria have been designated for licensing termination or unrestricted release, but the following criteria are used in designing nuclear facilities:

$\begin{array}{ll}\text { Surface } \alpha & 3.7 \times 10^{3} \mathrm{~Bq} / \mathrm{m}^{2} \\ \text { Surface } B, \gamma & 3.7 \times 10 \mathrm{~Bq} / \mathrm{m}^{2} \\ \text { Specific activity } & 74 \mathrm{~Bq} / \mathrm{g}\end{array}$

The Finnish utilities must produce reports outlining the methodology, time line, and waste volume of decommissioning. These reports must be updated every five years.

\subsubsection{Financial Provisions}

According to the Nuclear Energy Act, the power companies are responsible for the costs of nuclear waste management, including decommissioning costs. Decommissioning will be financed by a percentage of the assets collected yearly during power plant operation. Decommissioning must be financed beforehand through annual tax-exempt payments of a designated amount into the state nuclear waste fund. The payments are based on decommissioning plans and cost estimates, which are plant specific and must be revised at specified time intervals.

\subsection{FRANCE}

\subsubsection{Decommissioning Strategy}

French decommissioning strategies correspond to the type of facility: (a) total immediate decommissioning for fuel-cycle plants, hot cells, and pool reactors and (b) partial immediate decommissioning for reactors, which may be maintained in this state for long periods without incurring excessive costs and are designed to ensure containment of the residual radioactivity within a compact volume.

The decommissioning procedures (and the authorization to proceed with the dismantling operations) are the same as those applicable to the creation, commissioning, and significant alteration of nuclear installations (Nuclear Energy Agency 1986, 1991; Pflugard 1990). After a facility ceases operation, the first stage deals with the final shutdown. The operator submits a safety analysis report, the final shutdown report, and proposes subsequent surveillance and maintenance arrangements. The 
dismantling procedure depends on the final (or provisionally final) state reached after work. Three cases are possible:

- If residual activity higher than that of the basic nuclear installation classification threshold for temporary waste repositories remains after dismantling, the installation remains classified as a basic nuclear installation. Permission to proceed is granted only after the operator prepares a safety analysis report that describes and analyzes the dismantling operations and surveillance phase attained in the final state.

- If radioactive materials remain in the installation and the total activity no longer requires a basic nuclear installation classification but is greater than the thresholds established within the framework of classified installation legislation for the protection of the environment, dismantling is authorized on the basis of a safety analysis report analogous to that in the first case. The final state of the installation will be authorized in accordance with the procedure provided under the legislation. When this procedure is completed, the installation is classified under the legislation.

- The level of dismantling (level 3) makes it possible to make the installation and the site available for use without restriction. In this case, the final state does not require a special procedure. The work is authorized on the basis of a safety analysis report. When the work is completed, and on the basis of a report accompanied by a record of the final radiological state, the installation is declassified.

The operator remains responsible for the safety of its installation even after operations finally cease and must demonstrate that the dismantling work, the final state attained, and the surveillance of the installation afford an acceptable level of safety. The safety authority ensures safety through an examination of the operating organization's dossier and by surveillance at different stages of dismantlement.

\subsubsection{Regulations}

Decommissioning operations in France are not subject to separate regulatory provisions, but constitute a special subset of regulations covering all nuclear facilities. No mandatory decommissioning time table is stipulated, and no technical options are imposed; these are the responsibility of the operator. 
Two criteria must be met if materials or objects are to be exempted from regulatory control: the individual risk must be low enough not to warrant regulatory concern, and radiation protection, including the cost of regulatory control, should be optimized.

\subsubsection{Financial Provisions}

The utility takes into account the decommissioning costs in the same way as it does the construction costs. The annual funding from the Atomic Energy Commission covers the dismantling of surplus facilities.

\subsection{FEDERAL REPUBLIC OF GERMANY}

\subsubsection{Decommissioning Strategy}

In accordance with the general technical definitions of decommissioning, three stages can be distinguished (Nuclear Energy Agency 1986, 1991; Kato 1992; Willie and Bertholdt 1987):

- Stage I. Shutdown of the reactor, or the system, as well as the removal of the mobile activity inventory and the final shutdown of individual systems no longer required for operation. Several years are usually required for this stage.

- Stage II. Safe enclosure of the facility for approximately 30 years. The first containment barrier is reduced to the smallest possible size.

- Stage III. Complete removal of the facility.

Because of technical and economic factors, the last two stages are subdivided as follows: (1) safe enclosure without an appreciable extent of demolition; (2) safe enclosure of the activated zone (reactor tank zone) and complete dismantling of the nonradioactive and contaminated components; and (3) complete dismantling of the plant with a permit.

\subsubsection{Regulations}

Germany does not have any specific rules or regulations for decommissioning. The decommissioning of a nuclear facility is based on Article 7.3 of the German Atomic Energy Law, the Radiation Protection Regulation and the Atomic Procedural Provisions. In most cases, the regulations and specifications of plant construction are transferred and applied analogously. The 
Federal Ministry for the Environment, Protection of Nature, and Reactor Safety (BMU) is responsible for issuing directives for the respective licensing procedures. The BMU delegates execution of the procedure to the respective ministries of the federal states.

Article 7.3 of the German Atomic Energy Law applies when a facility is shut down and irreversible modifications to the system are planned; as a result, a new start-up can be avoided. The decommissioning details are specified in the licensing procedure and largely granted by a permit. The permit applies to individual dismantling processes and process steps, as well as to the limit values for the waste treatment or radioactivity release. The permit is granted on the basis of the safety report and detailed supplementary documents (i.e., extensive plans, the dismantling manual, all radiation protection and working instructions, and the safeguards report).

The design of nuclear facilities allows for the ultimate decommissioning of the plant, security, and ultimate disposal. Components are to be designed and arranged in such a way that they can be decontaminated, disassembled, and transferred inside the plant with the lowest possible radiation exposure. Nuclear power plants are required to be in such a condition that they can be decommissioned in compliance with radiation protection regulations. A concept for the removal of the plant after its final shutdown must be provided in the licensing procedure for new nuclear power plants.

In 1986, decontamination was required to meet the activity levels for unrestricted release as stipulated by the recommendations of the International Commission on Radiological Protection. A more detailed guideline for release criteria is now being considered. The following criteria have been established as a basis of licensing for release:

Surface Contamination

$\alpha$ emitters

$B, \gamma$ emitters

$0.037 \mathrm{~Bq} / \mathrm{cm}^{2}$

Specific Activity

$0.37 \mathrm{~Bq} / \mathrm{cm}^{2}$

$10^{-4}$ allowance/g

\subsubsection{Financial Provisions}

The German utilities are responsible for all decommissioning actions, including the cost. 


\subsection{ITALY}

\subsubsection{Decommissioning Strategy}

Italy's strategy for decommissioning of nuclear facilities is in an experimental stage (Nuclear Energy Agency 1986, 1991; Pflugard 1990; ENEL 1990). No major decommissioning activities have been conducted thus far. The policy on power plant decommissioning is to implement IAEA stage 1 and possibly stage 2 , and then to delay implementation of stage 3 for up to 30 years. In the interim between stages 2 and 3, appropriate procedures for total dismantling will be developed with current technologies and suitable facilities for the disposal of the decommissioning wastes. The state electricity board will perform decommissioning on the basis of the following steps: (1) achieving passive safe storage conditions within 10 years from the date of final plant shutdown; (2) continuing passive safe storage for a substantial period; and (3) full dismantlement of the site for unconditional release.

\subsubsection{Regulations}

All aspects of safety, radiation protection, and environmental protection fall under appropriate national regulations. Specific reference to decommissioning activities is included in the revision of Presidential Decree N.185, February 13, 1964, which is the basic law on nuclear safety and radiation protection.

\subsubsection{Financial Provisions}

No official funding system sets aside funds for decommissioning because the two organizations that own Italian nuclear installations are state owned. Therefore, no problem exists in the financing of decommissioning activities, other than suitable budgeting.

\subsection{JAPAN}

\subsubsection{Decommissioning Strategy}

The basic policy for decommissioning of nuclear power plants in Japan was established by the Atomic Energy Commission (Kato 1992; Jayawardene and Armstrong 1986; Nakamura 1994; IAEA 1993). It states that nuclear power plants should be dismantled as early as possible after shutdown. The current strategy for decommissioning assumes a short (5- to 10-year) storage period 
in stage 1 before final dismantling of the plant: It is assumed that the site will be returned to a greenfield condition. Decommissioning must be conducted in such a way that the safety and protection from radiation exposure of workers and the general public are ensured; radiation exposure of workers is ALARA; the site is used effectively after decommissioning; and harmony with the local community is secured. However, the decommissioning procedure for each plant is decided on a case-by-case basis.

The reactor licensee is responsible for managing radioactive wastes generated at the reactor site. Before dismantling is completed, all radioactive wastes from dismantling must be transferred to interim storage or a final disposal site. The low-level wastes should be treated according to their radiation levels. Wastes to be categorized into the nonradioactive group are determined by a subcommittee of the Nuclear Safety Commission. Nonradioactive wastes can be categorized as follows: (1) noncontaminated materials, as clearly shown by past records and installation situations, and (2) neutron-activated materials with radiation levels less than or equal to natural background.

\subsubsection{Regulations}

The Nuclear Reactor Regulations Law covers decommissioning of a nuclear facility. This law requires the licensee to submit a decommissioning plan to the responsible minister before proceeding. This document must address the decommissioning methods, schedule, and treatment of nuclear fuels and radioactive wastes. The minister may designate the decommissioning method or establish requirements for decontamination, safety, etc., if necessary. Licensing termination and unrestricted release criteria are not mentioned in the Japanese regulations. Japan has no national policy on radioactive waste disposal.

\subsubsection{Financial Provisions}

The licensee is entirely responsible for decommissioning. Utilities began to reserve funds to cover decommissioning costs in 1989. A tax-free system for decommissioning funds, introduced in 1990 , allows the utilities to reserve $85 \%$ of total decommissioning cost tax-free. The total decommissioning cost is determined on the basis of the estimated weight of the wastes from each plant. 


\subsection{NETHERLANDS}

\subsubsection{Decommissioning Strategy}

The Netherlands has no formal decommissioning strategy (Nuclear Energy Agency 1986). It is generally envisaged that surplus nuclear facilities will eventually be dismantled, but not for several decades after the facility has been shut down.

Safety is a high priority. No activity should spread to the environment; thus, the outer containment and its filter, monitoring, and ventilation systems should be kept operational through the end of the project.

\subsubsection{Regulations}

The Netherlands has no specific decommissioning regulations; such activities would be covered by the regulations governing public health and safety, as specified in the Nuclear Energy Act. The ALARA principle is used for all procedures, resulting in a low personnel radiation dose combined with reasonable time and cost considerations.

\subsubsection{Financial Provisions}

The owners of commercial power reactors are responsible for decommissioning and its cost.

\subsection{NORWAY}

\subsubsection{Decommissioning Strategy}

Norway has no formal decommissioning strategy (Nuclear Energy Agency 1986). Four research reactors and one pilot reprocessing plant have been or are now operating in Norway, but no nuclear power is to be produced before 2000; hence, little official attention has been paid to waste management or decommissioning. 


\subsubsection{Regulations}

The operating licenses for the Norwegian research reactors, issued under the provisions of Act No. 28 of May 12, 1972, concerning nuclear energy activities, require the owner of the facilities to prepare decommissioning plans and present them to the Nuclear Energy Safety Authority three years before the licensing permit is due to expire.

\subsubsection{Financial Provisions}

Norway has no policy for financing decommissioning activities.

\subsection{RUSSIA}

\subsubsection{Decommissioning Strategy}

The former Soviet Union failed in an attempt to adopt in situ entombment as the decommissioning strategy for reactors, but the Russian government and industry that inherited most of these reactors still does not have a clear decommissioning or dismantling plan (Nucleonics Week 1992).

Opening a new nuclear power plant site is difficult and dictates a decommissioning strategy in which structures from a closed unit will serve as a replacement unit and be built on the same site. It is believed that long-term conservation of a partially dismantled nuclear power unit (equivalent to IAEA stage 2 or NRC SAFSTOR) will be chosen as a strategy for practically all reactors, to allow radioactive decay and postpone further expenditures. Among the problems associated with decommissioning reactors is that of spent-fuel disposal. Dismantling wastes are kept on-site at decommissioned reactors as both cemented or bitumenized liquid wastes and compacted, encapsulated solid wastes, awaiting the creation of regional waste repositories.

\subsubsection{Regulations}

Russia has no regulations covering decommissioning and disposal of dismantling wastes. A first draft of a regulatory document for decommissioning production reactors exists, and it is hoped that it will eventually cover power reactors as well. Framework laws on nuclear energy and waste management have been pending for years. 


\subsubsection{Financial Provisions}

It is not known how decommissioning of existing and future projects will be financed. In the former USSR, a system existed to finance decommissioning through electricity rates. Although the system must be reestablished, it appears likely that the current owner of the Russian nuclear power plants would pay for decommissioning. However, no law or regulation regarding financing currently exists.

\subsection{SPAIN}

\subsubsection{Decommissioning Strategy}

Spain is developing criteria and plans for decommissioning nuclear power plants and research reactors, as well as for stabilizing tailings from mining and milling activities (Nuclear Energy Agency 1986, 1991; Pflugard 1990). For light-water reactors, total dismantling within 5-10 years is being contemplated for planning and cost estimating purposes. Decommissioning activities would begin five years after the final shutdown. All three stages of decommissioning will be undertaken in rapid succession over a period of five years. Specific decommissioning plans will be prepared on a case-by-case basis as shutdown approaches.

\subsubsection{Regulations}

Regulatory levels are being determined to establish an exemption level. Concerning other criteria for unrestricted release, the applicable regulations provided $a$ priori special situations to be exempted from the general licensing procedure. An exemption policy for below-regulatory-concern wastes is considered a significant issue in decommissioning as it has a large impact on radioactive waste volumes and thus on costs. ENRESA, the organization responsible for all aspects of radioactive waste management in Spain, is working with Spanish regulatory authorities in close cooperation with Commission of the European Communities research programs to develop criteria and methodologies for the application of exemption practices. ENRESA manages a final storage facility for low- and intermediate-level wastes containing short-lived beta-gamma emitters and a limited amount of alpha-bearing waste. These wastes are subject to ENRESA's acceptance criteria, and storage will consist of near-surface burial in concrete facilities. 


\subsubsection{Financial Provisions}

A system of payment on account has been established to finance future decommissioning activities. A certain percentage of all electricity sales is collected to fund back-end activities. Income resulting from this quota, combined with accumulating interest, should be sufficient to cover projected future expenditures.

\subsection{SWEDEN}

\subsubsection{Decommissioning Strategy}

Sweden has no formal decommissioning strategy because the decommissioning of the first large nuclear power reactor is still more than 20 years in the future (Nuclear Energy Agency 1986, 1991). No choice has been made between dismantling soon after final reactor shutdown and allowing a cooling period before dismantling.

\subsubsection{Regulations}

The Act of Nuclear Activities of January 12, 1984, specifies that the licensee for nuclear activities is to (1) take necessary measures to maintain safety during decommissioning and dismantling and to safely handle and dispose of nuclear waste; (2) ensure research and development is conducted as needed to fulfill the foregoing requirements; and (3) prepare a program for research and development work. The program is to present a survey of all measures that may be necessary and specify the measures to be taken within a period of at least six years.

Measures concerning the health and safety of workers and the public are prescribed in the Radiation Protection Act, and detailed regulations are provided by the National Institute for Radiation Protection.

\subsubsection{Financial Provisions}

According to Swedish legislation, the reactor owners are responsible for the back-end of the nuclear fuel cycle, including the decommissioning of the nuclear power plants. A fee is levied on nuclear electricity production to cover the future costs.

The Financing of Future Expenses for Spent Nuclear Fuel Act, issued January 12, 1984, stipulates that the holder of a license to possess or operate a nuclear power reactor shall defray the 
costs for (1) safe handling and final safe disposal of spent nuclear fuel from the reactor and radioactive waste deriving from it; (2) safe decommissioning and dismantling of the reactor installation; and (3) required research and development.

\subsection{THAILAND}

\subsubsection{Decommissioning Strategy}

In accordance with general technical definitions (Decommissioning Plan for Thai Research Reactor 1994), there are three decommissioning stages:

- Stage 1 (Storage and Surveillance). This stage refers to the shutdown of the reactor, removal of the radioactivity inventory, and final shutdown of individual systems no longer required for operation. Normally, this stage takes several years and requires maintenance of ventilation systems as well as continuous surveillance and monitoring.

- Stage 2 (Restricted Site Use). This stage refers to the safe enclosure of the facility for a number of years. The contaminated areas must be cleaned up and sealed to prevent access, and the contaminated parts must be removed. The site can be used in a restricted manner and with limited surveillance and monitoring.

- Stage 3 (Unrestricted Site Use). This stage refers to the total dismantling or complete removal of all structures and equipment to below prescribed limits. The area can be entered without restriction and can be exploited for unregulated alternative application.

\subsubsection{Regulations}

National regulations on decommissioning research reactors are expected to be completed in 1995. The Office of Atomic Energy for Peace Acts is the authority on the regulatory roles pursuant to the Atomic Energy for Peace Act; therefore, members of the regulation and control staff will establish a low-level regulation on decommissioning based on IAEA (1990). 


\subsubsection{Financial Provisions}

Thailand has no policy for financing decommissioning activities.

\subsection{UNITED KINGDOM}

\subsubsection{Decommissioning Strategy}

The current policy for decommissioning radioactive facilities follows these guidelines (Nuclear Energy Agency 1986, 1991; Pflugard 1990; Watkinson 1990; Passant 1988; Modern Power Systems 1993; Whyte 1988): (1) where practicable, refurbish for further radioactive use; (2) decommissioning and disposal proceed as soon as practicable; and (3) facilities awaiting decommissioning are placed on a defined care and surveillance status. Nuclear stations will be decommissioned in three stages. This proposed strategy is not yet approved, nor has regulatory approval been obtained. These stages are summarized as follows.

- Stage 1. All fuel will be removed from the reactor and subsequently stored off site (typically for 0-5 years from the end of generation). Accumulated operational wastes may be processed for disposal. The plant will not be dismantled; it will be kept under surveillance and in a safe condition. Safety requirements will essentially be the same as those that would apply to a period of extended maintenance shutdown.

- Stage 2. Stage 2 consists of three phases:

- Phase 1: Preparation for care and maintenance (typically 5-7 years from the end of generation).

- Phase 2: Care and maintenance (typically 7-35 years from the end of generation).

- Phase 3: Construction of safe-store structures (typically 35-37 years from the end of generation).

Radioactive and nonradioactive plant components and buildings external to the biological shield or the prestressed concrete pressure vessel will be dismantled, as appropriate, and subsequently removed from the site. The remaining reactor structure will be kept under surveillance. 
Because of the quantity of material handled during this stage, effective safety measures must be in place to control contamination. Radiation and contamination control zones similar to those adopted during reactor operations will be set up, and restrictions will not be lifted until it is certain that no hazard remains.

- Stage 3. The pressure vessel, reactor internals, biological shield, and residual buildings will be dismantled to a clear site to permit redevelopment or release for alternative use. Dismantling to greenfield status or in situ decommissioning of the active plant and building may be deferred for up to 100 years.

The time scale for this work will vary from station to station. However, each stage could take five to seven years. Stage 2 will follow as soon as practicable after stage 1 , but the decision for stage 3 to follow immediately after stage 2 or to be deferred for any period up to 100 years will depend on the circumstances and policy existing at that time.

\subsubsection{Regulations}

Under the provisions of the Nuclear Installations Act of 1965, the licensee is responsible for protecting the public from hazards associated with ionizing radiation and the overall safety of its nuclear sites. This responsibility will continue during the decommissioning phase. Under Section 5 (1) of this act, the site license may be revoked at any time by the Health and Safety Executive (HSE) or surrendered by the licensee. However, the revocation or surrender of a license does not end the licensee's "period of responsibility," which will terminate only when the HSE agrees that there is no longer any danger from ionizing radiation from the site. Throughout the decommissioning phase, radiological protection standards will be maintained in accordance with ALARA principles. Statutory limits in force when the decommissioning work is carried out will serve as dose limits.

The total radiological burden to workers from the entire decommissioning process is not expected to exceed 10 person-Sv per station, spread over many years. This limit is, of course, additional to the normal requirements of the various acts associated with health and safety at work.

The Radioactive Substances (Substances of Low Activity) Exemption Order of 1986, Statutory Instruments No. 1002, defines exemption limits relevant to decommissioning as a maximum specific activity of $0.4 \mathrm{~Bq} / \mathrm{g}$. This limit may be increased to $1 \mathrm{~Bq} / \mathrm{g}$ for wastes left behind on a decommissioned site. 
The Department of the Environment regulates the disposal of radioactive wastes from the dismantling of contaminated plant and structures. The 1965 (amended) Nuclear Installations Act gives the Department the necessary authority to assume the regulatory role for waste disposal, which must be authorized under the 1960 Radioactive Substances Act. Transportation of wastes between the facility and off-site storage and disposal locations is covered by legislation that reflects IAEA regulations. The Department of Transport issues the approvals and authorizations.

\subsubsection{Financial Provisions}

The United Kingdom has no official funding scheme for decommissioning. Plant owners and operators are responsible for decommissioning costs.

\subsection{SCOTLAND}

\subsubsection{Decommissioning Strategy}

Scotland's decommissioning strategy has three stages (Nuclear Energy Agency 1991; Pflugard 1990): (1) operational closure; (2) equipment disposal (over years); and (3) site clearance (up to a century later).

Once decommissioning has begun, much of the plant will no longer be operational and will not need further maintenance. Therefore, the operating and maintenance staff can be reduced. However, no new procedures can be adopted until revised maintenance, inspection, and test schedules have been drawn up and formally approved. The defueling in stage 1 occurs under conditions different from those of normal operation because new fuel is not being loaded and the size of the fuel inventory, and its decay heat, are continually being reduced. Therefore, changes in operating methods will be taken into account, and revised operating rules and procedures will be drawn up and approved.

The current government policy is that operational wastes should be removed and conditioned as soon as possible, a policy that is, however, not necessarily consistent with minimizing radiation dose to operators or optimizing cost. The lack of both a disposal facility and a conditioning method acceptable to the disposal facility operator defines the time scale for treatment and disposal of low-level waste. A typical sequence for low-level waste would be retrieval; sorting and cutting, if necessary; conditioning of the waste to a solid form; buffer storage of the conditioned wastes to allow curing; and transport from the power station to the disposal repository. Optimizing the disposal route requires systematic assessment of radiation dose, economics, power station site use, lifetime 
and safety case of existing operational waste stores, government policy, continued licensability of the stores, and availability of disposal facilities.

The removal of any radioactive equipment, whether for reuse elsewhere, or for disposal, will require approval, and because the time scale for approval may be protracted, detailed planning several years in advance is necessary.

\subsubsection{Regulations}

The Regulatory Authorities require that the arrangements for ensuring safety (i.e., the supervisory safety structure and management) should be submitted for approval before decommissioning. They also require programs with phased decommissioning to be submitted for approval, and they specify that consent may be required before proceeding from one phase to the next. In addition, they require information on policy, final objectives, time table, and person-dose for all three stages and overall strategies for decommissioning and waste management based on an examination of options. These requirements ensure that the full program is considered and planned through to the end of stage 3 , with reduced detail in the later stages. The changeover from the arrangements for an operating station to those for a decommissioning station must be specified carefully to avoid ambiguities and overlap.

Scottish Nuclear operates or decommissions power stations only in accordance with conditions embodied within nuclear site licenses issued to the company by the HSE under the provisions of the 1965 Nuclear Installations Act. The licenses require Scottish Nuclear to manage operations so that waste is minimized, to accumulate wastes only in approved stores, and to maintain proper records of such accumulations. In the special case of decommissioning, detailed arrangements are required before the HSE will allow Scottish Nuclear to begin decommissioning and to continue beyond agreed stages in the decommissioning program.

The Authorizing Departments (Department of Environment, Department of Transport, and Ministry of Agriculture, Fisheries, and Food) and the Nuclear Installations Inspectorate have statutory powers to ensure that standards are maintained so that potential exposure of the public to radioactivity from waste disposal is kept ALARA and that the public is safeguarded, both now and in the future.

The formal government responsibility for overall radioactive waste management strategy rests with the Department of the Environment and the Scottish and Welsh offices. The Authorizing Departments have published assessment principles for disposal proposals. These principles were established only after extensive public consultation and following advice from the Radioactive Waste Management Advisory Committee, an independent body responsible for advising the Secretary of State for the Environment. 


\subsubsection{Financial Provisions}

Scotland has no official funding scheme for decommissioning costs. Plant owner/operators are responsible for decommissioning costs. 


\section{REFERENCES}

"Decommissioning Plan for Thai Research Reactor-1/M1", 1994, Proceedings of the Decontamination and Decommissioning Conference, Knoxville, Tenn.

DOE, 1985, "Safety Requirements for the Packaging and Transportation of Hazardous Materials, Hazardous Substances, and Hazardous Wastes," U.S. Department of Energy Order 5480.3.

DOE, 1986, "Safety of Department of Energy-Owned Nuclear Reactors," U.S. Department of Energy Order 5480.6.

DOE, 1988a, "Defense Decontamination and Decommissioning (D\&D) Program Overview," U.S. Department of Energy, Richland Operations Office.

DOE, 1988b, "Radioactive Waste Management," U.S. Department of Energy Order 5820.2A.

DOE, 1989, "Comprehensive Environmental, Response, Compensation, and Liability Act Requirements," U.S. Department of Energy Order 5400.4.

DOE, 1990a, "Environmental Protection, Safety, and Health Protection Information Reporting Requirements," U.S. Department of Energy Order 5484.1.

DOE, 1990b, "General Environmental Protection Program," U.S. Department of Energy Order 5400.1.

DOE, 1991, “Quality Assurance,” U.S. Department of Energy Order 5700.6C.

DOE, 1992a, "Baseline Technology for Radioactive Material Transportation Packaging Systems," U.S. Department of Energy Order 1540.3A.

DOE, 1992b, "Conduct of Operations Requirements for DOE Facilities," U.S. Department of Energy Order 5480.19.

DOE, 1992c, "Facility Approvals, Security Survey, and Nuclear Materials Survey," U.S. Department of Energy Order 5634.1B.

DOE, 1992d, "Materials Transportation and Traffic Management," U.S. Department of Energy Order 1540.1A.

DOE, 1992e, “NEPA Compliance Program,” U.S. Department of Energy Order 5440.1E. 
DOE, 1992f, "Planning and Preparedness for Operational Emergencies," U.S. Department of Energy Order 5500.3A.

DOE, 1992g, "Project Management System," U.S. Department of Energy Order 4700.1.

DOE, 1992h, "Radiation Protection for Occupational Workers," U.S. Department of Energy Order 5480.11 .

DOE, 1992i, “Real Property Management,” U.S. Department of Energy Order 4300.1C.

DOE, 1992j, "Technical Safety Requirements," U.S. Department of Energy Order 5480.22.

DOE, 1993a, "Environmental Protection, Safety, and Health Protection Standards," U.S. Department of Energy Order 5480.4.

DOE, 1993b, "Occurrence Reporting and Processing of Operations Information," U.S. Department of Energy Order 5000.3B.

DOE, 1993c, "Radiation Protection of the Public and the Environment," U.S. Department of Energy Order 5400.5 .

DOE, 1994a, Decommissioning Handbook, U.S. Department of Energy, Office of Environmental Restoration.

DOE, 1994b, "EM-40 Overview Presentation for the Assistant Secretary of the Office of Environmental Management," U.S. Department of Energy, Office of Environmental Management.

DOE, 1994c, "Nuclear Safety Analysis Reports," U.S. Department of Energy Order 5480.23.

DOE, 1994d, "Personnel Selection, Qualification and Training Requirements for DOE Nuclear Facilities," U.S. Department of Energy Order 5480.20.

DOE, 1994e, "Radioactive Waste Management," U.S. Department of Energy Order 5480.2B.

DOE, 1994f, Radiological Control Manual, DOE/EH-0256T, Revision 1, U.S. Department of Energy, Assistant Secretary for Environment, Safety, and Health, Washington, D.C.

ENEL, 1990, Nuclear Power Station Decommissioning, Ente Nazionale per L'Energia Elettrica, Rome, Italy. 
IAEA, 1983, Decommissioning of Nuclear Facilities: Decontamination, Disassembly and Waste Management, Technical Report Series 230, International Atomic Energy Agency, Vienna, Austria.

IAEA, 1988, "Decontamination and Demolition of Concrete and Metal Structures during Decommissioning of Nuclear Facilities," Technical Report Series 296, International Atomic Energy Agency, Vienna, Austria.

IAEA, 1990, The Regulatory Process for the Decommissioning Nuclear Facilities: Safety Guide, International Atomic Energy Agency, Vienna, Austria.

Jayawardene, N.D., and Armstrong, P.J., 1986, "One-Piece On-Site Burial of Candu Reactors for Decommissioning," Spectrum '86, Proceedings of the American Nuclear Society International Topical Meeting on Waste Management and Decontamination and Decommissioning, Vol. 2, Niagara Falls, N.Y. (Sept 14-18).

Kato, W.Y., 1992, "Taipei, China - A High Technology Without Border - Nuclear," Proceedings of the 8th Pacific Basin Nuclear Conference, Brookhaven National Laboratory, Upton, N.Y. (April 12-16).

Lamberg, L., Ed., 1988, Present Status of Decommissioning in Finland, Third Finnish-German Seminar on Nuclear Waste Management 1986, Technical Research Center of Finland, Espoo, Finland (May).

Modern Power Systems, 1993, pp. 23, 25 (April).

Nair, R.P., Maan, M.A., and Schafer, S., 1986, "Comprehensive Radiological Protection Program - An Essential Element of Successful Decommissioning," Spectrum '86, Proceedings of the American Nuclear Society International Topical Meeting on Waste Management and Decontamination and Decommissioning, Vol. 2, Niagara Falls, N.Y. (Sept. 14-18).

Nakamura, M., 1994, Decommissioning of Nuclear Facilities in Japan, Office of Nuclear Fuel Cycle Back End Policy, Atomic Energy Bureau, Science and Technology Agency, Tokyo, Japan (Jan).

NRC, 1988, Final Generic Impact Statement on Decommissioning of Nuclear Facilities, NUREG-0586, U.S. Nuclear Regulatory Commission.

NRC, 1994, "Radiological Criteria for Decommissioning, Proposed Rule (10 CFR Parts 20, 30, 40, 50, 51, 70, and 72)," Federal Register 59(161):43200. 
Nuclear Energy Agency, 1986, Decommissions of Nuclear Facilities, An Analysis of the Variability of Decommissioning Cost Estimates, Organization for Economic Cooperation and Development, Paris, France.

Nuclear Energy Agency, 1991, Decommissioning of Nuclear Facilities, An Analysis of the Variability of Decommissioning Cost Estimates, Organization for Economic Cooperation and Development, Paris, France.

Nucleonics Week, 1992, "No Decommissioning Strategies Developed for Ex-Soviet Reactors," pp.12-13 (Nov. 5).

Passant, F.H., 1988, "Hinkley Point 'C' Power Station Public Inquiry," Proof of Evidence On-Site Radioactive Waste Management and Decommissioning, Central Electricity Generating Board, London, United Kingdom (Sept. 1).

Pflugard, K., 1990, Decommissioning of Nuclear Installations, Commission of the European Communities, Elsevier Applied Science, New York.

Watkinson, A.B., 1990, "Sellafield Primary Separation Plant Interim Summary Project Report," Spectrum '90 Proceedings of International Topical Meeting on Nuclear and Hazardous Waste Management, Knoxville, Tenn.

Whyte, I. L., 1988, "Decommissioning Offshore, Onshore and Nuclear Works," Proceedings of First International Conference on Decommissioning, London, United Kingdom.

Willie, H., and H. Bertholdt, 1987, "System Decontamination with Cord and Decontamination for Unrestricted Release," Proceedings of Nuclear Power Performance and Safety Conference, Vol. 5, Vienna, Austria (Sept. 28 - Oct. 2). 
APPENDIX A:

DRAFT DEPARTMENT OF ENERGY ORDER 5820.DDD, DECOMMISSIONING OF U.S. DEPARTMENT OF ENERGY CONTAMINATED SURPLUS FACILITIES 


\section{APPENDIX A:}

\section{DRAFT DEPARTMENT OF ENERGY ORDER 5820.DDD, DECOMMISSIONING OF U.S. DEPARTMENT OF ENERGY CONTAMINATED SURPLUS FACILITIES}

1. OBJECTIVE. To establish policies and guidelines for the deactivation, transfer, decontamination, and dismantling of contaminated surplus facilities (hereafter referred to as decommissioning) under U.S. Department of Energy (DOE) ownership or control.

2. APPLICABILITY. Except for the exclusions in paragraph $2 b$, the provisions of this order apply to all departmental elements and contractors performing work for the DOE that involves the decommissioning of contaminated surplus facilities.

a. Application to Contracts. All paragraphs of this order shall apply to contractors.

b. Exemptions. To avoid duplicate or conflicting requirements, DOE facilities, projects, and programs that are licensed or subject to regulation by the U.S. Nuclear Regulatory Commission (NRC) or an NRC Agreement State shall use the rules, standards, and criteria specified by the NRC or NRC Agreement State in lieu of this order. Also excluded from the provisions of this order are facilities and activities covered under Executive Order 12344 and Public Law 98-525.4.

\section{RESPONSIBILITIES.}

a. Assistant Secretary for the Environment, Safety, and Health (EH-1) acts as DOE's independent element for environment, safety, occupational safety, and health oversight of line management performance. EH-1 also has responsibility for establishing safety policy and implementing guidance. Specifically, EH-1 shall:

(1) Monitor and review the implementation plan for decommissioning programs to determine compliance with DOE environment, safety, and health requirements;

(2) Develop, promulgate, and maintain the policy requirements; guidance, and technical standards and provide advice and assistance, as requested, concerning safety policy as it relates to decommissioning programs; and 
(3) Concur on requests for temporary and permanent exemptions from the requirements of this order.

b. Cognizant Secretarial Officers (CSOs) are responsible for managing contaminated facilities under their jurisdiction and ensuring that these facilities, once designated as surplus to program needs, are safely shut down and transferred to the Office of Environmental Management (EM) for disposition. This responsibility includes surveillance and maintenance of the contaminated surplus facilities until responsibility has been transferred to EM or other organizations. Specifically, the CSOs shall:

(1) Grant temporary exemptions for up to one year from the provisions of this order after receiving concurrence from $\mathrm{EH}-1$ and $\mathrm{EM}-1$.

(2) Grant deviations from the Decommissioning Plan.

(3) Prepare and forward to EH-1 copies of decommissioning documents required by this order.

4. REQUIREMENTS. DOE organizations shall develop programs for the surveillance, maintenance, and decommissioning of contaminated facilities and document the programs in the Safety Analysis Report (SAR), as required by DOE Order 5480.23, "Nuclear Criticality Safety," as required by DOE Order 5480.24, and Environmental Protection, Safety, and Health Standards, as required by DOE Order 5480.4. The decommissioning programs shall be implemented as follows:

\section{a. General}

(1) Each DOE Operations Office shall prepare and maintain a complete list of contaminated surplus facilities to be decommissioned, both operating and shut down, under its jurisdiction. A continuous record of jurisdictional program responsibility and operational status for all contaminated surplus facilities shall be maintained by the cognizant organization for use in transition planning.

(2) Operational records (e.g., facility design drawings and modifications, operational history, characterization data on contamination levels, prior decontamination activities, and incident reports required by DOE orders) for all contaminated surplus facilities shall be maintained by the cognizant field organization for use in transition planning. 
(3) Planning for contaminated surplus facility decommissioning shall be initiated during the design phase for new facilities and before termination of operating facilities. If possible, contact should be made with EM to discuss transition plans before the surplus facility is shut down. Such plans shall consider the budget cycle to ensure adequate funding availability during and after facility transition. For facilities that have been declared surplus and for which no decommissioning planning has been initiated, planning activities in accordance with this order shall be initiated as soon as possible, according to DOE policy and programmatic objectives.

(4) CSOs or their designates shall be responsible for safe shutdown and transition of the contaminated facilities designated as surplus to program needs until they are formally transferred to EM. Thereafter, EM shall accept full responsibility for surveillance, maintenance, and/or decommissioning of the contaminated surplus facility according to the requirements of this order. Agreements to transfer facilities shall be put in writing and identify explicitly the concurrent transfer of responsibility for surveillance, maintenance, and decommissioning.

(5) Elements typically considered in an SAR, as defined by DOE Order 5480.23, shall be included in the Decommissioning Plan for the contaminated surplus facilities scheduled for decommissioning.

b. Facility Design. Facilities in which radioactive and/or hazardous materials are used shall be designed to simplify decommissioning and/or increase the potential for reuse. Features and procedures that simplify and facilitate decommissioning shall be identified during the planning and design phase on the basis of a proposed decommissioning method or conversion to other use, as required by DOE Orders 5480.30 and 6430.1A.

(1) Modifications to existing facilities shall also meet these design criteria. Guidance regarding features to be incorporated, as well as examples of such features, are provided in DOE Orders 5480.30 and $6430.1 \mathrm{~A}$ and cover reactor as well as nonreactor nuclear facilities.

(2) DOE Order 5480.30 also specifies design procedures to be met for nuclear facilities that will reduce waste volumes and occupational exposure during decommissioning.

c. Postoperational Activities. Deactivation of a contaminated surplus facility may be initiated before or after its transfer to EM, depending on the agreement between the donor CSO and EM. Deactivation shall be conducted in a manner that provides for the availability of needed services throughout the phases of postoperational activities (e.g., cooling systems for highlevel nuclear waste before processing, ventilation for the control of airborne particulate contamination, electrical systems for heating, lighting, communication, required controls, 
valving systems for the transfer of fluids in piping systems). After a contaminated surplus facility has been deactivated, it will await final disposition in a safe storage mode.

(1) During the deactivation process, DOE program organizations shall assess the extent of contamination at surplus facilities under their jurisdictions, document the potential for reuse and recovery of materials and equipment, and develop plans and schedules for decommissioning. The contaminated surplus facility and its systems can be decontaminated before, during, and/or after its deactivation. Projects consisting of one or more facilities shall be identified, as appropriate, and priorities shall be developed on the basis of the following:

(a) Maintaining employee and public health and safety;

(b) Protection of the environment;

(c) Compliance with the National Environmental Policy Act (NEPA), Resource Conservation and Recovery Act (RCRA), Comprehensive Environmental Response, Compensation, and Liability Act (CERCLA), Superfund Amendments and Reauthorization Act (SARA), Federal Facilities Compliance Act, and other contractual or legal requirements (including applicable state regulations such as NRC Agreement State regulations on radioactive waste), as well as DOE and Executive Orders that provide guidance on meeting the requirements of the acts. These include DOE Order 5440.1E, "NEPA Compliance Program"; DOE Order 5400.4, "Comprehensive Environmental Response, Compensation, and Liability Act Requirements"; and Executive Order 12580, "Superfund Implementation"; and

(d) Future site plans.

(2) Responsible DOE organization shall ensure that after the contaminated surplus facility is shut down, a surveillance and maintenance program is established to meet applicable radiation protection standards (DOE Order 5400.5, "Radiation Protection of the Public and Environment"; DOE Order 5480.1B, "Environmental Safety and Health Programs for Department of Energy Operations"; DOE N 5480.6, Radiological Control Manual; DOE/EH-0256T, Rev. 1; and DOE Order 5480.11, "Radiation Protection of Occupational Workers"); DOE Order 5840.19, "Conduct of Operations"; and hazardous, chemical, and safety standards, to maintain physical safety and security and reduce potential public and environmental hazards. All stored low-level waste produced as a result of the operational activities, high-level waste, and stored hazardous materials shall be removed. 
d. Decommissioning Project Activities. Decommissioning project activities include characterization, environmental review, planning and engineering, decommissioning operations, and postdecommissioning activities.

(1) Characterization. Baseline data for each project shall be collected to support a thorough physical, chemical, and radiological characterization to fulfill the appropriate requirements of the RCRA, CERCLA, and SARA. The baseline data shall include the following:

(a) Drawings, photographs, and other records reflecting the as-built and asmodified condition of the facilities and grounds, including existing protective barriers, and systems installed to ensure public, occupational, and environmental safety;

(b) The type, form, quantity, and location of hazardous chemical and radioactive material from past operations at the site; and

(c) Information on factors that could influence the selection of decommissioning alternatives, such as potential future use; long-range site plans required by DOE Order 4300.1C, "Real Property Management"; facility condition; and potential health, safety, and environmental hazards.

(2) Environmental Review Process. The RCRA, CERCLA, and/or SARA status of each project shall be identified, and a remedial investigation/feasibility study shall be performed, if required. On the basis of the results of the remedial investigation/ feasibility study and any additional data deemed necessary by the responsible field organization, an appropriate environmental review shall be performed according to the requirements of the NEPA, RCRA, CERCLA, and/or SARA. Candidate decommissioning alternatives shall be identified, assessed, and evaluated, and a preferred decommissioning alternative shall be selected on the basis of the results of the environmental review

(3) Planning and Engineering. Engineering planning for each project shall be conducted to support the environmental review process to ensure that alternative actions and associated environmental issues are identified and assessed and to support preparation of environmental documentation. Detailed engineering will be initiated after a preferred alternative is selected. EM will prepare a Decommissioning Plan. EH shall review the Decommissioning Plan and concur with it. The Decommissioning Plan shall include the following:

(a) A description and history of the contaminated surplus facility. 
(b) Physical, chemical, and radiological characterization data or references to such data and estimates of the quantities of each waste stream.

(c) A summary evaluation of decommissioning alternatives for the contaminated surplus facility, including the preferred alternative; alternatives include storage with surveillance/monitoring, restricted release, and unrestricted releăse.

(d) Plans for meeting requirements of the environmental review process (NEPA, RCRA, CERCLA, and/or SARA) and all necessary permits; cleanup criteria to be used; and applicable standard on which criteria is based.

(e) A discussion of the activities (scope of work) required to meet the objectives of the decommissioning alternative being considered.

(f) Summary of the organization responsible for the management of the decommissioning project. Discussion should cover plans for training, quality assurance, security (including nuclear safeguards), project controls, and subcontractor and procurement activities.

(g) A detailed discussion of the Health and Safety Program, including a description of the Occupational Safety and Health Agency (OSHA) and Health Physics Programs, covering as-low-as-reasonably-achievable (ALARA) implementation and projections of occupational radiological and chemical exposure for the decommissioning alternative being considered. This section documents all applicable safety requirements and measures to meet those requirements according to the requirements of DOE Order 5480.23.

(h) Discussion of the Waste Management Program, including a description of processes and systems to be used for the processing and disposal of wastes generated during the decommissioning activities. The Waste Minimization and Recycling Plan shall also be described. On the basis of the waste stream data, quantities shall be estimated for the decommissioning alternative being considered.

(i) Discussion of the final survey requirements that will detail the way the regulatory and cleanup criteria objectives will be met. Discussion can include the procedure for conducting final surveys, including instrumentation used and the recording of survey results. The results should include a final radiological and chemical survey report and an independent verification report. 
(j) Documents and records required for the closeout of the project. In addition to the final survey reports, a final project report, record of completion, certification docket, and appropriate public notices for facilities being released to the public shall be included in the project data package assembled at the end of the project.

Decommissioning Operations

(a) The decommissioning operations shall be conducted in accordance with the alternative selected in the environmental review and described in the Decommissioning Plan. Significant deviations from the Decommissioning Plan shall be approved by EM.

(b) Approval of the appropriate DOE office shall be obtained before initiating activities to demolish a DOE-owned contaminated surplus facility, according to the requirements of DOE Order 4300.1C, "Real Property Management."

(c) Status reports on project activities shall be prepared in accordance with the requirements of DOE Orders 1332.1A, "Uniform Reporting System," and 4700.1, "Project Management System," as appropriate.

(d) Decommissioning operations shall meet the appropriate general requirements in DOE Order 5820.2A and RCRA, where applicable, which provide guidance on storage and handling requirements.

\section{Postdecommissioning Activities}

(a) After decommissioning operations are completed, a final radiological and chemical survey report, an independent verification report, and a final project report shall be prepared. The final project report shall include a description of the project, the final status of the property, and the "lessons learned" (e.g., pitfalls and successes) from the project.

(b) The responsible DOE organization shall compile a project data package that includes the information stated in (8)(d)(3)(j) of this order.

(c) The responsible DOE organization shall ensure that any necessary long-term maintenance and surveillance or other safety controls are provided for the decommissioned facility. 
(d) The decommissioned facility may be released from DOE ownership according to the requirements of DOE Order 4300.1C, "Real Property Management."

(e) The decommissioned facility may be reused for other program activities that may or may not involve radioactivity or hazardous chemicals. If appropriate release criteria are not met, the property may be reused for other program activities that may or may not involve radioactivity or hazardous chemicals, provided that adequate safety controls are maintained.

e. Quality Assurance. Quality assurance practices shall be consistent with DOE Order 5700.6C, "Quality Assurance."

f. Implementation. This order shall become effective six months following its issuance. All new decommissioning projects will be planned and constructed in full compliance with this order. Special considerations are provided for decommissioning projects already under way at the effective date of this order. For projects in the earlier phases of decommissioning, the responsible DOE organization may request a temporary exemption from this order to allow the responsible organization time to define actions to integrate existing plans into the requirements of this order. For projects where significant decommissioning activities have taken place before the effective date of this order, a permanent exemption may be requested.

5. CONTACT. EH-64. 
APPENDIX B:

DRAFT STANDARDS 


\section{APPENDIX B:}

\section{DRAFT STANDARDS}

Several draft standards being prepared or planned cover topics that have previously not been addressed by any U.S. Department of Energy (DOE) standard. Draft standards are not usually adopted by DOE directives because they can be modified before they become final. However, because the topics of the following proposed standards are not covered by any other standards, Draft DOE Order 5820.DDD will invoke the following draft standards as guidelines when they become final:

- DOE-STD-XYZ-1, "Facility Design Features for Facilitating Decontamination and Decommissioning," will provide appropriate modifications to the implementation guidance related to the design features for decontamination and decommissioning in DOE Order 5480.30, "Nuclear Reactor Design Criteria," and DOE.NNFDC, "Non-Reactor Nuclear Facility Design Criteria."

- DOE-STD-XYZ-2, "Characterization for Decontamination and Decommissioning," will provide guidance on conducting surveys for radiological and hazardous substance contamination in connection with decontamination and decommissioning activities at formerly used DOE facilities.

- DOE-STD-XYZ-3, "Decommissioning Alternatives," will provide guidance on decommissioning alternatives, including, for example, no action, safe storage (mothballing), in-place entombment, and decontamination and dismantlement. This standard will also address recycle and reuse of materials, components, systems, and facilities.

- DOE-STD-XYZ-4, "Waste Storage and Handling and Acceptance Criteria," will provide guidance on the storage and handling of radioactive and hazardous wastes as well as the acceptance criteria for the disposal of these wastes. These criteria include those from the U.S. Environmental Protection Agency for hazardous and mixed wastes and from the U.S. Nuclear Regulatory Commission, Agreement States, and DOE for radioactive wastes.

- DOE-STD-XYZ-5, "Criteria for the Unrestricted Release of Sites, Facilities, Materials and Equipment," will provide guidance on meeting the criteria to be used for the unrestricted release of sites, facilities, materials, and equipment. 
- DOE-STD-XYZ-6, "Deactivation of Contaminated DOE Facilities," will provide guidance on the procedures for deactivating surplus facilities.

- DOE-STD-XYZ-7, "Surveillance and Maintenance of Deactivated DOE Nuclear Facilities," will provide guidance on the surveillance and maintenance programs that will be required to ensure that the facilities are prepared for final disposition in a safe, environmentally sound, and cost-effective manner. 